UNIVERSIDADE DE SÃO PAULO

FACULDADE DE FILOSOFIA, CIÊNCIAS E LETRAS DE RIBEIRÃO PRETO DEPARTAMENTO DE PSICOLOGIA E EDUCAÇÃO

PROGRAMA DE PÓS-GRADUAÇÃO EM PSICOLOGIA

\title{
Encontro Comunitário de Saúde Mental: um estudo fenomenológico
}

\author{
Laura Ferreira Crovador
}

Dissertação apresentada à Faculdade de Filosofia, Ciências e Letras de Ribeirão Preto da Universidade de São Paulo como parte dos requisitos para obtenção do grau de Mestre em Ciências. Área: Psicologia.

Ribeirão Preto 



\section{Encontro Comunitário de Saúde Mental: um estudo fenomenológico}

Dissertação apresentada à Faculdade de Filosofia, Ciências e Letras de Ribeirão Preto da Universidade de São Paulo como parte dos requisitos para obtenção do grau de Mestre em Ciências. Área: Psicologia.

Orientadora: Profa. Dra. Carmen Lúcia Cardoso

\section{Ribeirão Preto}


AUTORIZO A REPRODUÇÃO TOTAL OU PARCIAL DESTE TRABALHO, POR QUALQUER MEIO CONVENCIONAL OU ELETRÔNICO, PARA FINS DE ESTUDO E PESQUISA, DESDE QUE CITADA A FONTE.

FICHA CATALOGRÁFICA

Crovador, Laura Ferreira

Encontro Comunitário de Saúde Mental: um estudo fenomenológico, 2012.

77 p. : il. ; $30 \mathrm{~cm}$

Dissertação de Mestrado, apresentada à Faculdade de Filosofia, Ciências e Letras de Ribeirão Preto/USP. Área de concentração: Psicologia.

Orientador: Cardoso, Carmen Lúcia.

1. Encontro Comunitário de Saúde Mental. 2. Fenomenologia

3. Reforma Psiquiátrica. 4. Cuidado.

5. Promoção de Saúde Mental. 6. Serviços Substitutivos. 


\section{FOLHA DE APROVAÇÃO}

Nome: Crovador, Laura Ferreira

Título: Encontro Comunitário de Saúde Mental: um estudo fenomenológico.

Dissertação apresentada à Faculdade de Filosofia, Ciências e Letras de Ribeirão Preto da Universidade de São Paulo como parte dos requisitos para obtenção do grau de Mestre em Ciências, Área: Psicologia

Aprovado em ____ 2012

\section{Banca Examinadora}

Prof. Dr.

Instituição: Assinatura:

Prof. Dr.

Instituição: Assinatura:

Prof. Dr.

Instituição: Assinatura: 



\section{AGRADECIMENTOS}

Gostaria de agradecer, em primeiro lugar, a minha orientadora Dra Carmen Lúcia Cardoso, por ter me acolhido em seu grupo de pesquisa, possibilitado a realização deste estudo, e acima de tudo, pelas vezes que, diante de importantes divergências filosóficas, ter permitido que eu escrevesse meu trabalho de acordo com as minhas convicções. Agradeço os ensinamentos, a orientação e o respeito ao meu olhar como pesquisadora.

A meus pais, Antônio e Vera, por terem tido paciência e confiança para me apoiar em minha iniciativa de fazer o mestrado, mesmo que esta se apresentasse como algo abstrato e incerto para eles. Por me dar o apoio necessário para que eu seguisse a carreira que eu escolhi.

Ao Dr. Sérgio Ishara, por ter autorizado e apoiado meu projeto de estudo. Por sua disponibilidade e generosidade e pelas valiosas sugestões ao meu trabalho.

A Dra. Juliana Vendrúsculo, que ao longo dos últimos anos eu tenho tido a sorte e a felicidade de ter como supervisora. Por ter estado sempre ao meu lado na minha trajetória na Fenomenologia-existencial e pelas contribuições que enriqueceram este trabalho e, acima de tudo, por me ouvir, ensinar, corrigir e incentivar, confiando em mim sempre.

Ao Dr. Sílvio Yasui, pela disponibilidade para participar do exame de qualificação, por todas as suas sugestões que contribuíram para o desenvolvimento e aprofundamento deste trabalho.

As mais que queridas amigas Bia, Marina, Cláudia, Anamélia, Juliana e Thaisa por, sem querer, sem perceber, terem me ensinado sobre comunidade e o significado dessa vivência para a saúde mental e para o sentido da minha vida. Por terem me recebido de braços abertos nessa família linda que vocês são, e por nunca terem me deixado ir embora.

Ao Luciano, pelo seu amor, carinho, amizade e apoio incondicional. Por sua imensa paciência e pelo bom humor. Pela força e pelo incentivo. Por ser um parceiro na minha trajetória, neste trabalho e na vida.

Aos amigos Rafael, Eduardo, Lizandra, Daniela, Letícia e Bia pela amizade nos momentos de crise e por me ajudarem tanto, cada um a sua maneira. Por ouvirem minhas 
queixas, dúvidas, revoltas e inseguranças, e principalmente por acreditar o tempo todo na minha competência e na qualidade deste trabalho.

A CAPS, pelo financiamento deste trabalho.

A todos os participantes dos Encontros Comunitários de Saúde Mental, por sua generosidade ao dividir suas experiências e por sua abertura para falar e ouvir no evento. Por contribuírem muito para a construção da minha própria saúde mental, da minha prática clínica e da minha postura diante do outro, muito obrigada! 


\section{RESUMO}

Crovador, L. F. (2012). Encontro Comunitário de Saúde Mental: um estudo fenomenológico. Dissertação de Mestrado, Departamento de Psicologia, Faculdade de Filosofia, Ciências e Letras de Ribeirão Preto, Universidade de São Paulo.

O Encontro Comunitário de Saúde Mental (ECSM) é uma nova metodologia de ação em Saúde Mental, inserida no contexto do paradigma de compreensão e tratamento do sofrimento psíquico preconizado pelo movimento de Reforma Psiquiátrica. Promovido anualmente, o evento é destinada o usuários e ex-usuários de serviço de saúde mental, familiares, profissionais e estudantes da área, bem como para a comunidade em geral. Nesse sentido, o presente trabalho tem como objetivo produzir uma descrição dessa prática que permita a compreensão dos sentidos atribuídos por seus integrantes, durante sua participação no evento. Para atender a esse objetivo, foi adotado o referencial epistemológico e metodológico da Fenomenologia. Foram analisados dois registros em vídeo, correspondentes a dois eventos. Os vídeos foram transcritos na íntegra e as descrições foram submetidas à análise fenomenológica. A análise do fenômeno permitiu desvelamento de sentidos que compõem a estrutura do ECSM, a saber, Partilha, Valorização das Pessoas, Valorização das Relações, Aprendizado, Reconhecimento de Semelhanças, Satisfação, Gratidão e Experiência Comovente. Tais sentidos apontam para a compreensão do ECSM não apenas como um dispositivo técnico relevante para a área, mas fundamentalmente como uma atitude diferenciada diante do outro. A postura diante do outro e da saúde mental desvelada no estudo permitiu uma articulação do modo de acontecer do ECSM com a concepção de Ser e de Cuidado descritas pela filosofia de Martin Heidegger. O Encontro se constitui como um espaço no qual existe uma abertura para as pessoas, enfatizando o movimento de vir-a-ser de cada um. O ECSM cria um espaço de valorização dos participantes como pessoas que têm potencial para oferecer ajuda para a construção da saúde mental de todos os envolvidos. No evento, essa possibilidade de ajuda é realizada ressaltando a característica do ser humano como ser-com, e através da Partilha os participantes têm a possibilidade de co-construírem sua compreensão de si mesmos e da saúde mental. Os participantes revelam sua satisfação por participarem de um evento com essas características, que possibilita novos aprendizados e relatam terem se comovido com os depoimentos. Dessa maneira, o ECSM se desvela como um lugar de Cuidado, à medida em que seus participantes conversam e constroem possibilidades de existir. Assim, o ECSM se constitui como uma ação em saúde mental que trabalha no sentido da promoção de saúde de todos os envolvidos.

Palavras chave: Encontro Comunitário de Saúde Mental, Fenomenologia, Cuidado, Reforma Psiquiátrica. 



\begin{abstract}
Crovador, L. F. (2012). Community Meeting for Mental Health: a phenomenological study. Dissertação de Mestrado, Departamento de Psicologia, Faculdade de Filosofia, Ciências e Letras de Ribeirão Preto, Universidade de São Paulo.

The Community Meeting for Mental Health (Encontro Comunitário de Saúde Mental ECSM) is a new practice outlined within the context of the paradigm of understanding and treating mental suffering, as recommended by the Psychiatric Reform. Once a year, the event is promoted for and aimed at former mental health service clients and their relatives, workers and students of the mental health area, as well as the general community. Thus, the objective of the present study is to describe the referred practice in a way that would permit understating the meanings that its members assign to the event during their participation. In order to achieve the objective, phenomenology was chosen as the epistemological and methodological framework. An analysis was performed of two video recordings, corresponding to two events. The videos were fully transcribed and a phenomenological analysis of the descriptions was performed. The analysis of the phenomenon allowed for revealing the meanings that comprise the structure of the ECSM, which are: Sharing, Valuing Others, Valuing Relationships, Learning, Recognizing Similarities, Satisfaction, Appreciation, and Moving Experience. Those meanings point at understanding the ECSM not only as a technical device relevant to the area, but fundamentally as a differentiated attitude towards others. The posture towards others and towards mental health revealed in the present study permitted an articulation of the way that ECSM takes place with the concept of Being and of Care as described by Martin Heidegger. The Meeting is a place open to people, emphasizing each person's movement of becoming-to-be. The ECSM creates a place that values participants as individuals who have the power to help build the mental health of all those involved. At the event, that possibility of helping occurs with emphasis on the human feature of being-with, and, through Sharing, the participants have the opportunity to coconstruct their understating of themselves and of mental health. The participants reveal their satisfaction towards participating in an event with characteristics that allow for learning new things, and they report feeling moved with the statements. Thus, it is revealed that the ECSM is a place of Care, as its participants talk and create possibilities of existence. Therefore, the ECSM is a mental health action that works guided by the principles of the Psychiatric Reform, in the sense of promoting the health of all those involved.
\end{abstract}

Keywords: Community Meeting for Mental Health, Phenomenology, Care, Psychiatric Reform. 



\section{Prólogo - Um primeiro olhar}

O Encontro Comunitário de Saúde Mental (ECSM) é um tema que conecta três áreas que despertam meu interesse desde a graduação em Psicologia: a pesquisa como campo de atuação do psicólogo, a Fenomenologia como instrumento de compreensão do mundo e a prática na área da Saúde Mental e seus desafios. A possibilidade de articulação dessas áreas permite compreender como tal Encontro se tornou alvo do meu interesse no mestrado.

Desde quando entrei na faculdade de Psicologia me interessei pelo aprendizado e pela construção do conhecimento que a atividade de pesquisa proporciona. Entrei no programa de Iniciação Científica e fiz parte de um grupo de pesquisas que estudava a qualidade de vida de pessoas submetidas ao Transplante de Medula Óssea. Foi um trabalho que utilizou metodologias quantitativas e qualitativas em pesquisa, financiado durante dois anos pela FAPESP, no qual eu aprendi muito sobre o tema pesquisado, sobre a prática do psicólogo e sobre a vida. Esse trabalho resultou no artigo "Qualidade de vida de pacientes com Esclerose Múltipla antes do Transplante de Células-Tronco Hematopoéticas, que será publicado na revista Psicologia, Reflexão e Crítica.

Nesse percurso, tive contato com a Fenomenologia. A proposta de conhecimento do mundo, através do "retorno às coisas mesmas", da percepção da diferença entre a "atitude natural” e a “atitude fenomenológica” e suas implicações não só no campo acadêmico, mas nas possibilidades de atuação do psicólogo e na vida cotidiana das pessoas, me encantou e ainda me encanta. Estudar Fenomenologia me despertou o interesse de trabalhar com ela e, nesse sentido, o mestrado se configurou como uma oportunidade para desenvolver este trabalho.

Ao longo da graduação em Psicologia, a compreensão da saúde mental - e da dita loucura - me causava grande inquietação. O que significava ser louco e o que significava ser são? Do que precisavam os loucos e do que precisavam os sãos? Quando estudava a respeito dos movimentos de Reforma Psiquiátrica e das novas propostas de atenção à saúde mental acreditava que tal atenção não devia ser direcionada apenas às pessoas com quadros psiquiátricos, mas que o cuidado devia se estender a todas as pessoas.

No final da faculdade fiz estágio em uma instituição de saúde mental, construída a partir das propostas da Reforma Psiquiátrica. Durante essa experiência eu me perguntava se a produção de saúde mental realmente estava se realizando, pois o atendimento muitas vezes me parecia cristalizado em um modelo ambulatorial. 
Após a conclusão do curso de graduação, tive a oportunidade de conhecer o ECSM. Participei do evento, me encantei pelo seu formato e pela experiência que esse formato propiciava. O acolhimento, o sentimento de pertença e a conversa sobre temas que tocam a todas as pessoas indistintamente foram ao encontro de minhas inquietações a respeito da saúde mental.

Conversando com minha orientadora, soube que o Encontro acontecia há muitos anos, mas que ainda não havia nenhum estudo sistematizado sobre ele no formato de tese ou dissertação. Nesse momento surgiu a oportunidade de conectar as três áreas do meu interesse e iniciei o projeto de mestrado como um estudo fenomenológico acerca de uma ação nova, original e a meu ver muito promissora no campo da saúde mental. 


\section{SUMÁRIO}

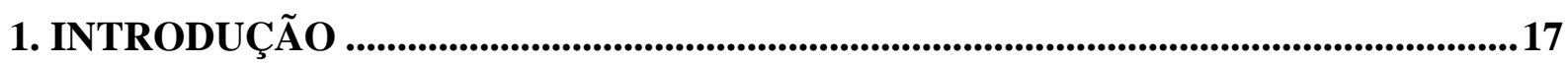

1.1 Breve histórico acerca dos movimentos de Reforma Psiquiátrica................................17

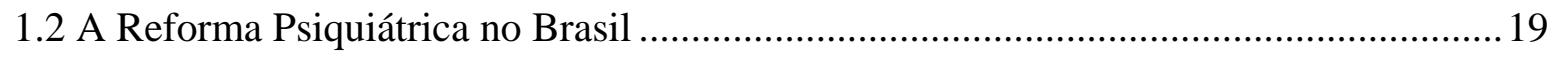

1.3 O Encontro Comunitário de Saúde Mental como nova proposta de atuação em Saúde

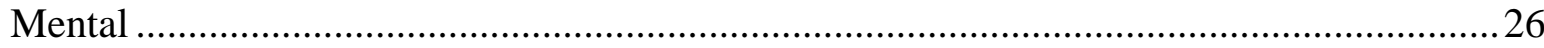

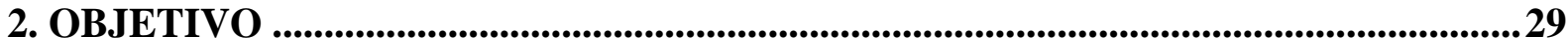

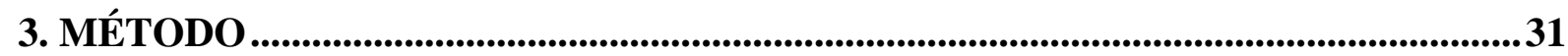

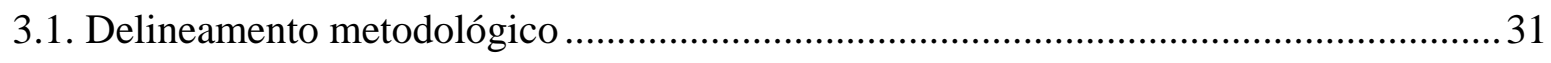

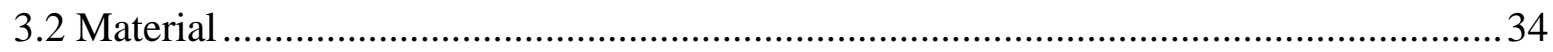

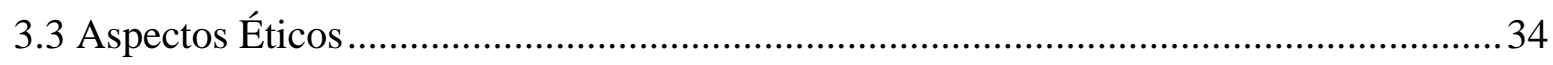

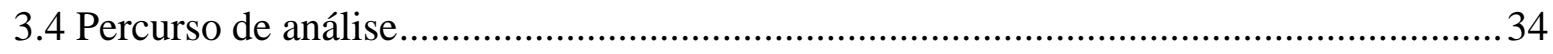

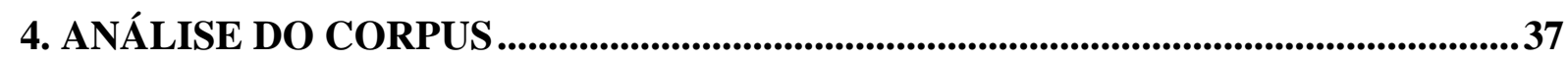

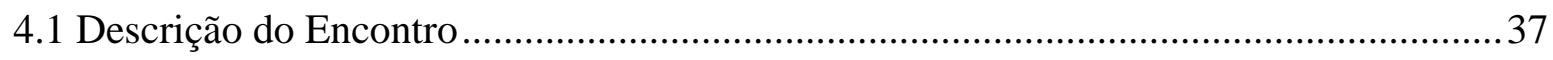

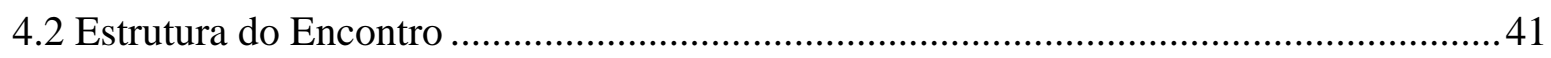

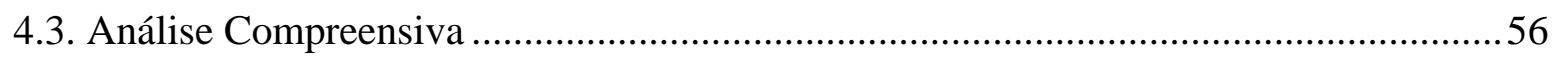

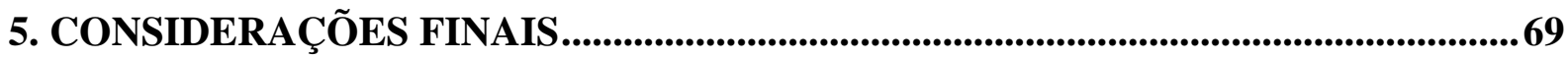

6. REFERÊNCIAS BIBLIOGRÁFICAS …........................................................................ 71

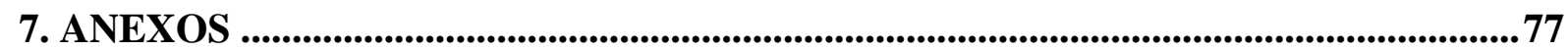

7.1 Autorização do Comitê de Ética em Pesquisa - Anexo 1............................................ 77 



\section{INTRODUÇÃO}

\subsection{Breve histórico acerca dos movimentos de Reforma Psiquiátrica}

O cuidado com a saúde mental foi pautado, ao longo da história, de acordo com a concepção de homem e de sofrimento mental de cada época. Os movimentos de Reforma Psiquiátrica, desenvolvidos em diversos países, contribuíram para operar transformações fundamentais nas concepções e nas práticas de atenção na área da saúde mental.

Após a revolução francesa, a figura do louco denunciava a falta de universalidade dos valores instituídos de liberdade, igualdade e fraternidade. Uma vez que esses preceitos consideravam o ser humano em sua racionalidade, o louco não era incluído como participante de direito desses valores. Segundo Robaina (2010), a liberdade se baseava na capacidade do homem racional fazer suas escolhas e vender sua força de trabalho, e sem participar desse universo, o louco também estava excluído do princípio de igualdade, já que não se ajustava ao modo de produção vigente. A autora completa a tríade da revolução francesa dizendo que, para o louco, o princípio de fraternidade tornou-se a tutela segregante que o afastou cada vez mais de sua condição de cidadão. Rosa (2002) aponta que foi nesse contexto intelectual e cultural que se instituiu o hospital psiquiátrico, realocando o louco para dentro dos limites do manicômio, tirando-o de seu lugar junto à família.

A partir desse entendimento, o louco foi considerado como um ser apartado da sociedade e desprovido de cidadania. As pessoas em sofrimento psíquico eram consideradas incapazes de participar da sociedade, uma vez que, tendo seu juízo racional prejudicado, eram consideradas anormais e consequentemente perigosas (Kraepelin, 1988).

O hospício, através do isolamento terapêutico, pretendia possibilitar a cura e o conhecimento da loucura a um só tempo. O isolamento passou a ser visto e valorizado como um ato terapêutico, ao oferecer o tratamento moral e a cura para a loucura, como um ato epistemológico, pois era nele que se dava o diagnóstico e o conhecimento da loucura e, ainda, visto como ato social, já que protegia a sociedade do perigo da convivência com os loucos (Kraepelin, 1988).

O tratamento do louco era compreendido como a eliminação dos sintomas e o controle da loucura e foi o principal aporte para a constituição da prática médica-psiquiátrica. A psiquiatria transformou o louco em um objeto de estudo como corpo doente e limitou-se a definir, catalogar e gerir essa doença (Basaglia, 1985). 
Delgado (1991) afirma que a hegemonia dos hospitais psiquiátricos, presente desde o século XIX, garantia à família e à sociedade o alívio das dificuldades da convivência com a loucura, acarretando a cronificação dos quadros dos pacientes e a perda dos vínculos familiares.

Após a Segunda Guerra Mundial, surgiram na Europa e nos Estados Unidos iniciativas de humanização dos hospitais psiquiátricos e a busca de possibilidades de reabilitação do louco. Tal possibilidade teria sido aventada, segundo Robaina (2010), a partir da demanda social por forças produtivas para reconstruir os países no pós-guerra.

Nesse período, em diversos países da Europa e dos Estados Unidos, cresceram as denúncias a respeito da exclusão social produzida pela forma de assistência ao doente mental. Tais manifestos possibilitaram debates que iniciaram o movimento das transformações no cuidado com a saúde mental (Campos \& Soares, 2005).

Surgiram nesses países movimentos de contestação ao conjunto de saberes e práticas que compunham o tratamento no âmbito da atenção psiquiátrica. Os movimentos eram contra o paradigma racionalista problema-solução, comumente aplicado em Psiquiatria, e pretendiam realizar uma reforma neste modelo, propondo novos arranjos técnicos e científicos (Rotelli, et al., 1990).

No Canadá, nos Estados Unidos e na Europa foram realizadas reformas legislativas e assistenciais que diminuíram o número de hospitais psiquiátricos e de internos. Essa redução se deu através da implantação de novos modelos de atenção em saúde mental e da incorporação dos direitos civis das pessoas com transtornos mentais (Campos \& Soares, 2005).

As Reformas Psiquiátricas dos anos 60, na maioria dos países da Europa, se propunham a superar de forma gradual o modelo manicomial. Para atingir tal objetivo, buscou-se a criação de serviços na comunidade, o deslocamento da intervenção terapêutica para o contexto social das pessoas, a promoção de saúde mental e a reabilitação (Rotelli et al, 1990).

No mesmo período, o movimento de Reforma na Itália propôs a desinstitucionalização do paciente psiquiátrico em relação aos serviços de saúde mental. A Reforma italiana tornouse um complexo processo que mobilizou os sujeitos sociais envolvidos e transformou as relações de poder entre os pacientes e as instituições (Rotelli et al, 1990).

O movimento de reforma da assistência em Psiquiatria conhecido por Psiquiatria Democrática, liderado por Franco Basaglia, tinha como objetivo denunciar práticas segregantes e desumanas que buscavam o controle social, e ainda revolucionar as concepções 
e terapêuticas vigentes (Randemark et al, 2004). Tal modelo propunha uma nova forma de compreender e lidar com a loucura, rompendo com as bases científicas, culturais e políticas que alicerçavam o paradigma da psiquiatria clássica (Robaina, 2010). Ou seja, o movimento buscava romper com o modo de compreensão linear da loucura, baseado em relações de causa e efeito, e rever o lugar da instituição psiquiátrica como modo de tratamento (Kantorski, 2001).

Segundo Rosa (2002), esse modelo se concentra na questão da emancipação do paciente e das possibilidades de troca entre os diferentes atores sociais. O objetivo da cura dos sintomas é substituído pela reinscrição das pessoas em sofrimento mental no mundo social.

Nessa proposta, a horizontalização do poder entre profissionais e usuários, bem como entre os diferentes saberes que constituem o campo da saúde mental, é uma meta a ser conquistada. O paradigma proposto por Basaglia prevê a substituição do hospital psiquiátrico por serviços de base comunitária e articula essas mudanças à transformações macrossocietárias (Robaina, 2010).

Este movimento levou à criação da Lei italiana $n^{\circ} 180 / 78$, que proibia o tratamento e a internação dos pacientes com transtornos mentais em hospitais psiquiátricos, prevendo sua desativação e gradativa substituição por serviços comunitários (Kinoshita, 1987).

\subsection{A Reforma Psiquiátrica no Brasil}

Durante os anos 70, no Brasil e na América Latina, ocorreram movimentos que visavam à reformulação e reorganização da política de saúde mental buscando humanizar o tratamento oferecido aos pacientes. O movimento foi desencadeado num momento de intensa mobilização social pelo retorno da ordem democrática e foi fortemente influenciado por movimentos de reforma ocorridos na Europa e nos Estados Unidos (Oliveira \& Alessi, 2003).

As transformações propostas pelo movimento de Psiquiatria Democrática na Itália tiveram grande influência no processo de Reforma no Brasil (Randemark et al., 2004). A Reforma Psiquiátrica, segundo Campos e Soares (2005) foi constituída como um conjunto de aparatos legislativos visando legalizar e implementar o processo de desinstitucionalização.

No início, a Reforma Psiquiátrica Brasileira tinha como meta a humanização do atendimento aos pacientes internados em hospitais psiquiátricos, depois passou a ter como objetivo a reinserção social, o resgate da cidadania e da singularidade desses pacientes. Para alcançar tal objetivo, a Reforma tinha como premissa a desinstitucionalização das pessoas com transtornos mentais, a desconstrução do aparato manicomial e a criação de serviços que 
buscassem a reabilitação psicossocial das mesmas e ainda a construção de uma nova concepção da doença mental e da prática assistencial (Randemark et al., 2004; Suiyama et al., 2007). Embora de implementação gradual, a desinstitucionalização se constituía como uma das propostas centrais da reforma, diferenciada de uma proposta de desospitalização (Randemark et al., 2004).

Segundo Campos e Soares (2005), a desinstitucionalização pode ser definida como o processo de desconstrução do paradigma clássico da Psiquiatria e de simultânea construção de um contexto teórico e prático acerca do sofrimento psíquico, com a invenção de novas realidades. Não se trata de oferecer serviços alternativos para o cuidado com a saúde mental, mas de substituir as compreensões e práticas reducionistas e segregantes do paradigma anterior.

A Reforma da assistência Psiquiátrica brasileira buscava uma transformação na atenção, ou seja, nas ações de atendimento e cuidado às pessoas em sofrimento mental, através de mudanças na compreensão do processo saúde-doença e no modelo técnicoassistencial que organiza a prática dos profissionais da área, além de sustentar ações jurídicas e valores culturais (Yasui \& Costa-Rosa, 2008). Os autores afirmam que o novo modelo de trabalho deve basear a sua organização na ruptura com o modelo tradicional de doença-cura, orgânica e hierarquizada, com ações de cuidado centradas na sintomatologia e na intervenção medicamentosa.

Segundo Mendes (2006), a organização das ações de cuidado devia se afastar do modelo de atenção médica e trabalhar no sentido da criação de um modelo de atenção à saúde integral. De acordo com Yasui e Costa-Rosa (2008), a saúde integral deve ser compreendida como o modo de levar a vida, em seus aspectos físicos, psíquicos, sociais, culturais, econômicos e ambientais.

No Brasil, o principal grupo que impulsionou as discussões acerca das necessidades de transformações nas práticas em Saúde Mental foi o Movimento dos Trabalhadores de Saúde Mental (MTSM). Segundo Amarante (1996) o MTSM formou um movimento social amplo, pois apresentava propósitos no sentido da restituição da cidadania do louco - negada pela tutela e pela clausura - e de uma crítica às bases teórico-práticas da psiquiatria, bem como às imagens sociais demarcadas pelo antigo paradigma.

Tal movimento defendia a desintegração dos dispositivos institucionais que levavam à cronificação da doença mental, tais como a falta de individualidade, o tratamento impessoal, o abuso de psicofármacos, o distanciamento da realidade social e familiar, entre outros, e buscava a ressocialização dos internos (Delgado, 1987). Lima e Teixeira (1995) apontam que 
o MTSM se posicionou contra o processo de privatização da saúde, devido às características e deformações do sistema psiquiátrico brasileiro.

As ações e discussões promovidas por profissionais da saúde, usuários e familiares em diversos fóruns políticos e acadêmicos contribuíram para que em 1989 fosse apresentado ao Congresso Nacional o Projeto de lei $n^{0}$ 2.675/89, conhecido como Projeto Paulo Delgado ou "lei antimanicomial", que pretendia extinguir progressivamente os manicômios e substituí-los por outros recursos assistenciais (Brasil, 1989). Depois de 12 anos de sua apresentação no Congresso Nacional, a Lei 10.216/2001 foi aprovada, amparando legalmente a mudança no modelo de tratamento que busca substituir o isolamento da pessoa em sofrimento psíquico pela sua reintegração ao convívio com a família e a comunidade (Brasil, 2011). Nesse contexto de revindicações, profissionais de saúde mental se articularam em torno da discussão e criação de novas possibilidades de intervenção na área, contribuindo para a continuidade deste processo. (Amarante \& Torre, 2001; Gonçalves e col., 2002)

Em relação aos desafios de implementação do novo modelo de assistência em saúde mental, Costa-Rosa (2000) diferencia dois conjuntos de saberes e práticas: o modo asilar e o modo psicossocial, que surgiu a partir das críticas ao modo asilar e do exercício de novas possibilidades práticas. As principais diferenças entre os dois modos se dão em relação às concepções de “objeto" e de "meios” de trabalho, às formas de organização institucional e às formas de relacionamento com os usuários. No modo asilar, o sofrimento psíquico é considerado como oriundo de determinações orgânicas. Essa concepção causal leva a organização de um tratamento medicamentoso visando a completa eliminação dos sintomas. No modelo psicossocial é atribuída maior importância à pessoa em sofrimento psíquico, que é vista em suas dimensões orgânicas e socioculturais, como participante principal do tratamento. Segundo o autor o tratamento é composto por psicoterapias, socioterapias, laborterapias e dispositivos de reintegração social, além da medicação, com o objetivo da reinserção social do usuário. Em relação à forma de organização institucional, no modo asilar poucas pessoas participam das tomadas de decisão, restando à maioria obedecer as determinações estabelecidas. No modo psicossocial é enfatizada a participação dos usuários e da comunidade nas decisões, valorizando a autogestão e a interdisciplinaridade na organização institucional. O relacionamento com os usuários, no modelo asilar, é caracterizado pela interdição institucional nas relações e nos diálogos, que são verticais, entre “sãos” e “doentes”. No modelo psicossocial, a interdição é substituída pela interlocução na instituição, criando um espaço para ouvir o usuário e perceber suas demandas, horizontalizando as relações. Nesta perspectiva considera-se necessária uma transformação 
ampla no paradigma que orientava o cuidado em saúde mental, saindo de um modelo asilar para o psicossocial.

É necessário ressaltar que a simples mudança de estrutura de atendimento não garante, em si mesma, a transformação da antiga maneira de lidar com o sofrimento mental. É a mudança do modelo de atenção à saúde mental que passa pela mudança da organização institucional, que poderá construir novas formas de olhar para as questões do sofrimento mental (Costa-Rosa 2000).

As diretrizes do modelo de atuação proposto pela Reforma apontam para a eliminação do tipo de assistência que produzia a exclusão e a marginalização das pessoas com transtornos mentais e para a construção de uma rede de ação no âmbito da saúde mental que promova a integração social e familiar das mesmas (Oliveira \& Alessi, 2003). Nesse sentido, é importante ressaltar que a reinserção social não deve ser entendida como uma simples devolução do usuário à sociedade ao retirá-lo do ambiente hospitalar, mas implica na invenção de novas possibilidades de integração do sujeito no corpo social (Amarante, 1996). Nesse processo devem estar envolvidos todos os atores sociais que fazem parte do processo saúde-doença, ou seja, usuários, familiares, profissionais de saúde e a comunidade em geral. (Lussi et al., 2006).

A reabilitação psicossocial deve ser entendida como um conjunto de ações que visam valorizar as potencialidades do indivíduo que sofre psiquicamente, através de diferentes recursos e serviços, e ainda contemplar três vértices da vida humana: a casa, o trabalho e o lazer. Para alcançar esses objetivos, é fundamental que o indivíduo em sofrimento psíquico seja reinserido na vida em sociedade, ou seja, retome sua autonomia e cidadania, exercendo sua possibilidade de circular nos espaços da cidade e construindo novas relações sociais (Mielke et al., 2011).

Para França Neto (2009), o manicômio tem a função de contenção da diferença, de tudo o que pode ser subversivo para a sociedade, ou seja, a exclusão dos que já são excluídos como cidadãos. Nesse sentido, Saraceno (2001) afirma que a instituição interditava as possibilidades de trocas, impedindo que os pacientes egressos de longas internações psiquiátricas se tornassem efetivamente sujeitos de suas vidas.

Já a Reforma se apresentaria como um movimento inverso, visando a inclusão do que foi excluído, possibilitando que a loucura se recoloque de uma maneira socialmente diferente. Wetzel \& Kantorski (2004) afirmam que os serviços que buscam a inserção social do paciente devem transformar as relações estabelecidas entre este, a equipe, a família e a comunidade, 
incluindo a mudança de papéis sociais, a democratização dos serviços e a responsabilização da comunidade nos objetivos do atendimento.

Nesse sentido, a possibilidade de participação dos usuários nos serviços de saúde tem sido ampliada e se constitui como um componente de grande importância na formulação de políticas de saúde (Vázquez et al., 2003). Porém, existe um descompasso entre tais conquistas obtidas na legislação e o cotidiano da prática dos serviços de saúde. (Cohn, 2000; Côrtes, 2002; Cotta et al., 2000)

De acordo com Almeida et al. (2010) as associações de usuários, familiares e profissionais de saúde mental contribuem para a reorganização da rede institucional que vem sendo constituída ao longo dos anos, pois conseguem produzir novas maneiras de lidar com a diferença, realizar questionamentos sobre a suposta incapacidade do usuário e estabelecer novas relações entre loucura e sociedade. De acordo com os autores essas associações são capazes de promover possibilidades de rupturas, pois produzem um espaço de potência no interior de uma área onde tradicionalmente imperavam a tutela e a opressão, dando vozes aos usuários e seus familiares como atores importantes no processo da Reforma. Figueiró (2009) afirma ainda que a importância das associações não deve ser medida apenas por sua capacidade de luta e participação política, mas também por sua produção do empoderamento dos atores envolvidos, ou seja, na ampliação de suas possibilidades de decisão relacionada às suas vidas.

Segundo Amarante e Torre (2001), a construção do protagonismo do usuário deve ser coletiva e requer a substituição da concepção de usuário-objeto pela realização de um usuárioator. Os autores afirmam que se faz necessária a destituição das representações sociais da loucura como doença mental, inferioridade ou incapacidade, substituindo-as pela afirmação da loucura como diferença.

Essa transformação tem sido realizada, de acordo com os autores, por iniciativas de reinvenção da cidadania e de empoderamento daqueles que estavam tradicionalmente delegados ao silêncio. Segundo Almeida et al. (2010), o objetivo de tais iniciativas seria a construção da autonomia, a intensificação da potência de vida e o aumento da possibilidade de decisão dos usuários.

Neste contexto de transformação, é valorizada a atuação em equipe multiprofissional, vinculada a um território de base comunitária, a integralidade do cuidado, a intersetorialidade e a integração em rede do nível primário ao especializado com enfoque interinstitucional (Nunes, Jucá \& Valentim, 2007). Para atingir essas metas é indicada a criação de uma rede de serviços composta por Centros de Atenção Psicossocial (Caps), Hospitais-dia, Serviços 
Residenciais Terapêuticos, leitos em hospitais gerais, centros de convivência, ações de saúde mental na Estratégia de Saúde da Família (ESF), entre outros (Zambenedetti, 2009).

Segundo Wetzel e Kantorski, (2004) os serviços substitutivos ainda não se consolidaram como tal, pois não foram efetivos em seu objetivo de substituir o sistema asilar no país. Contudo as autoras reafirmam o potencial de tais serviços, apontando para a necessidade de avaliações dos mesmos com o objetivo de alcançar na prática a transformação proposta pela Reforma.

Segundo Yasui e Costa-Rosa (2008) o processo de Reforma Psiquiátrica passa por avanços e dificuldades, pois as mudanças em curso enfrentam resistências oriundas de vários setores. As instituições de Saúde Mental engajadas no processo de implantar o novo modelo assistencial ainda se deparam com práticas hegemônicas do antigo modelo, que buscam superar.

Os CAPS surgiram buscando se tornar um espaço de produção de novas práticas sociais para lidar com o sofrimento psíquico de uma maneira nova, diferente da tradicional (Amarante, 2001). Consolidados na III Conferência Nacional de Saúde Mental, os CAPS assumiram um papel central no campo das práticas de saúde mental no país, como um dispositivo estratégico para a reversão do modelo hospitalar (Brasil, 2002).

Entretanto, Mello \& Furegato (2008) descrevem que os profissionais dos CAPS têm revelado sua preocupação com a possibilidade do usuário viver uma nova e velada institucionalização, devido a sua longa permanência em atendimento nesses serviços. Zambenedetti (2009) aponta para a falta de portas de saída dos serviços, denunciando a falta de constituição de uma rede, pois os usuários chegam, são atendidos e ficam.

Em estudo recente realizado com profissionais de um CAPS, Mielke et al. (2011), ressaltam a necessidade dos atendimentos ocorrerem de acordo com a demanda dos usuários, mas sempre baseando-se na compreensão de que a alta faz parte do tratamento. É importante explicitar que a alta não deve ser vista como desassistência, uma vez que reflete a possibilidade de articulação com demais serviços da rede que atendam o usuário em suas necessidades no momento em que ele não necessita mais do atendimento intenso e especializado proporcionado pelo CAPS. Segundo Mielke et al (2011), a ausência da alta nos serviços apontaria para um retrocesso ao modo hospitalocêntrico, se a mesma for justificada pela exclusão prolongada do usuário da vida em sociedade.

De acordo com Yasui e Costa-Rosa (2008) os CAPS têm funcionado seguindo modelos verticalizados na aproximação com usuários, reproduzindo ações funcionalistas que 
propõem a adaptação aos desajustados. Os autores apontam para uma proposta de ação que exige a superação desse paradigma.

A Estratégia de Atenção Psicossocial (EAPS) propõe um modelo de ação que situa a Saúde Mental como campo da Saúde Coletiva, e concebe a saúde e o adoecimento como resultantes de um processo social complexo. Nessa perspectiva, a EAPS aponta para um modelo de trabalho que reflita a lógica da cooperação, que não distinga o processo de ação dos efeitos dessa ação e dos beneficiários destes (Yasui e Costa-Rosa 2008). Os autores apontam a formação dos profissionais de saúde como um impasse na concretização da Reforma, pois a mudança de paradigma necessária para a implantação do novo modelo assistencial está ausente na formação básica dos mesmos. Assim, tais profissionais se vêem diante da necessidade de construir propostas de trabalho, fundadas na ruptura com a maioria dos conceitos presentes durante seus anos de formação, bem como com algumas concepções éticas e ideológicas.

Yasui e Costa-Rosa (2008) afirmam que os profissionais não aprendem a lidar com a demanda dos usuários dos serviços de saúde mental, pois não são preparados para ouvir o usuário em sua dor para além de seus sintomas e doença e para construírem estratégias facilitadoras da autonomia e da participação dos usuários. Dessa forma, os profissionais de saúde se encontram cotidianamente com um grande desafio de expandir e consolidar mudanças para as quais nem sempre foram preparados em seus cursos de graduação.

Para conseguir concretizar as diretrizes da Reforma, os autores apontam como necessárias a formação permanente desses profissionais, que permita a redefinição e reorganização de seu trabalho, a articulação de diferentes setores da sociedade, de maneira a viabilizar a criação e expansão de uma rede de cuidados e atenção fundada nos princípios de integralidade e participação popular.

França Neto (2009) ressalta que o que está em jogo atualmente é a interdição promovida não apenas pelo hospital psiquiátrico, mas também pela sociedade, que destitui o louco de sua condição de cidadão, suspendendo seus direitos e sua responsabilidade. Inserido em um contexto de necessidade de novas propostas no âmbito da saúde mental, o presente trabalho pretende responder a uma necessidade acadêmica e social ao produzir um estudo qualitativo a respeito de uma nova iniciativa no campo da saúde mental, a saber: o Encontro Comunitário de Saúde Mental. 


\subsection{O Encontro Comunitário de Saúde Mental como nova proposta de atuação em Saúde} Mental

A partir da formalização das diretrizes da Reforma Psiquiátrica, tornaram-se necessárias novas iniciativas no âmbito da saúde mental, que proporcionem ao usuário atendimento, reabilitação e reinserção na sociedade. O início das atividades que possibilitaram a construção do ECSM se deu em 1997, no Hospital das Clínicas da Faculdade de Medicina de Ribeirão Preto-USP (HC-FMRP - USP), sob a coordenação do psiquiatra Dr. Sergio Ishara. O Encontro Comunitário de Saúde Mental, no qual se centra o presente estudo, é uma ação que está vinculada a outros Grupos Comunitários que se realizam a partir da proposta de oferecer uma modalidade de cuidado na perspectiva psicossocial, afinada com as proposições da Reforma Psiquiátrica.

Inicialmente, os encontros eram organizados a partir de uma perspectiva psicoeducativa, com o desenvolvimento de atividades em grupo que proporcionassem aos usuários dos serviços de saúde mental e a seus familiares o acesso a informações consideradas importantes para o tratamento.

Chamados de "Encontros de Psicoeducação", esses eventos ocorriam uma vez por ano, e eram abertos à participação de profissionais de serviços de Saúde Mental, usuários, familiares e à comunidade em geral. As atividades nesses encontros tinham como objetivo favorecer o conhecimento acerca das doenças e de seus tratamentos, porém, já nesses grupos havia um espaço reservado para depoimentos de usuários e familiares, e um momento para a organização de uma mesa redonda sobre temas relativos à saúde mental.

A troca de conhecimentos - clínicos e vivenciais - propiciada nesses encontros apontou para a capacidade de todos os participantes da atividade oferecerem e receberem ajuda nesse enquadre. Assim, os depoimentos vivenciais de usuários e familiares se tornaram cada vez mais valiosos para a organização do evento, que reconhecia neles uma fonte de ajuda à comunidade. Pesquisas realizadas com os participantes dos Grupos de Psicoeducação reiteram a observação dos organizadores, da identificação da ajuda proporcionada pelos depoimentos para a saúde mental dos mesmos.

A partir dessa perspectiva, a proposta dos grupos foi amplamente reformulada para contemplar o potencial de ajuda dos depoimentos vivenciais e para construir uma abordagem dos temas referentes à saúde mental em um âmbito mais amplo do que o anterior, centrado nos aspectos clínicos e terapêuticos. Nesse período, os grupos se tornaram semanais e 
passaram a se chamar "Grupo Comunitário de Saúde Mental”, para que o nome do grupo refletisse de maneira mais adequada o enfoque das atividades realizadas.

Atualmente os Grupos Comunitários acontecem com uma frequência que varia de semanal a trimestral, de acordo com a instituição de saúde onde ocorrem. São os grupos ao longo de todo o ano que produzem o Encontro Comunitário de Saúde Mental, que constitui o foco do presente estudo.

O Encontro Comunitário de Saúde Mental é organizado pela equipe do Hospital-dia do Hospital das Clínicas da Faculdade de Medicina de Ribeirão Preto (HCFMRP) - USP de Ribeirão Preto, em parceria com o Centro de Psicologia Aplicada da Faculdade de Filosofia, Ciências e Letras de Ribeirão Preto. Atualmente tais eventos buscam contribuir para o compartilhamento do cotidiano numa perspectiva de ajuda mútua, de cuidado e construção da saúde mental de todos os envolvidos.

O Encontro Comunitário de Saúde Mental se estrutura a partir da realização de grupos semanais e mensais nos quais usuários, familiares e a comunidade são convidados a compartilhar experiências em uma perspectiva de construção da saúde mental. Atualmente os grupos semanais são realizados no Hospital Dia do HC-FMRP-USP, enquanto grupos comunitários de frequência mensal e trimestral têm sido realizados em outros serviços da rede de saúde pública de Ribeirão Preto e de algumas cidades da região.

Os grupos semanais se constituem como uma roda de conversa, da qual participam aproximadamente 40 pessoas, realizados sob a coordenação de um profissional do serviço de saúde, com duração de uma hora e trinta minutos. Alguns grupos são realizados aos sábados, com a mesma estrutura, visando ampliar a possibilidade de participação da comunidade. Estes grupos têm duas horas de duração e contam com a participação de aproximadamente 50 pessoas.

A conversa que se desenvolve nos grupos é orientada por um tema central, escolhido através da identificação das necessidades emergentes dos participantes. Em geral os temas escolhidos são abrangentes, de maneira que propiciem a contribuição dos participantes com suas experiências pessoais, como por exemplo: “A vida acontecendo" e "Descobertas Preciosas - pessoas e acontecimentos” . Todos os grupos são abertos ao mesmo público: usuários e ex-usuários do serviço, familiares, estudantes e profissionais da área da saúde e demais interessados da comunidade.

Uma vez por ano, o Encontro Comunitário de Saúde Mental, alvo deste trabalho, tem sido realizado em auditório da Universidade de São Paulo (USP) de Ribeirão Preto. O evento é estruturado em torno da conversa sobre um tema geral de saúde mental, através da 
realização de mesas redondas, compostas por representantes de todos aqueles aos quais os grupos comunitários estão abertos. A estrutura organizativa deste Encontro é maior, e conta com a presença de participantes dos grupos semanais e mensais, além de novos integrantes, totalizando cerca de 300 pessoas. Aqueles que participaram dos grupos menores ao longo do ano são convidados a darem seus depoimentos nas mesas redondas no Encontro anual.

Busca-se a valorização das experiências pessoais, o favorecimento do olhar para o cotidiano e o exercício de um papel de protagonismo junto à comunidade. Através desta prática, os acontecimentos do cotidiano são discutidos e podem propiciar a construção da saúde mental de todos os participantes, além de constituírem uma oportunidade para a desconstrução de esteriótipos e para a partilha de saberes entre os participantes.

Assim, o Encontro Comunitário de Saúde Mental constitui-se como um fechamento dos grupos do ano e também de divulgação do programa de atividades que ocorre ao longo do ano, ao ampliar a rede de contatos e incluir a participação de novas pessoas, inclusive de outras cidades. As pessoas são convidadas a dar seus depoimentos em uma perspectiva de ajuda mútua para a construção da saúde mental de todos os envolvidos.

Diversos estudos acerca dos Grupos Comunitários e do potencial de ajuda dessas práticas vêm se desenvolvendo para auxiliar na construção e delineamento de encontros futuros. É nesse conjunto de pesquisas que se insere o presente trabalho. 


\section{OBJETIVO}

O objetivo geral do presente trabalho é produzir um estudo sistematizado acerca de uma nova iniciativa no âmbito da saúde mental - o Encontro Comunitário de Saúde Mental.

Os objetivos específicos do presente trabalho são:

a) Descrever o Encontro Comunitário de Saúde Mental

b) Compreender o sentido do acontecer do Encontro Comunitário de Saúde Mental 


\section{MÉTODO}

\subsection{Delineamento metodológico}

Uma vez que os objetivos do trabalho são descrever e compreender os sentidos de um fenômeno humano, optou-se por uma metodologia de investigação qualitativa em pesquisa. Segundo Holanda (2002), a pesquisa qualitativa se constituiu como um avanço para as ciências humanas, pois se apresentou como um recurso para apreender os sentidos das experiências.

O autor afirma que o método qualitativo constrói um espaço de interlocução com o humano, que busca os significados subjacentes ao dado objetivo. Dessa maneira, tais métodos possibilitam o estabelecimento de novos paradigmas para as ciências humanas e sociais, uma vez que permitem uma modalidade de investigação que transcende os dados empíricos (Holanda, 2002).

Nesse sentido, o presente trabalho foi estruturado sem enquadrar ou delimitar nenhum aspecto previamente, uma vez que "tomar o novo como uma nova forma de saber preexistente é castrá-lo no que tem de novidade" (Gonzalez Rey, 2005 p.18). Para atingir os objetivos de descrição e compreensão dos sentidos do Encontro Comunitário de Saúde Mental foi adotado o referencial teórico-metodológico da Fenomenologia.

Desde a sua constituição, a fenomenologia foi um movimento filosófico que guardou grande proximidade e interesse pela área da Psicologia (Dartigues, 2003; Forghieri, 1993; Holanda, 2002; Husserl, 1965; 1985; 1992). A Fenomenologia foi escolhida como metodologia de investigação do presente trabalho por suas características de valorização da experiência, e por sua atitude de olhar para esta de uma maneira que possibilite captar sua riqueza de manifestações, sem tentar reduzí-la ou enquadrá-la em conceitos pré-definidos.

Será realizada uma breve caracterização desta linha de pensamento, pois não é possível separar a metodologia de investigação fenomenológica do referencial filosófico e epistemológico da Fenomenologia (Boemer, 1994). No final do século XIX, surgem as chamadas ciências humanas, área de conhecimento que determinava aquelas ciências que tinham o ser humano como objeto de conhecimento. Nesse período, a forma de pensamento hegemônico de produção do conhecimento era uma concepção empirista e determinista, que buscava leis de causalidade necessárias e universais para todo objeto de conhecimento, inclusive os fenômenos humanos (Coltro, 2000).

Tal modelo tratava os fenômenos humanos de maneira análoga aos fenômenos naturais, o que levava a uma compreensão restrita e fragmentada dos mesmos, devido à 
complexidade inerente a sua existência. Essas limitações denunciaram a necessidade de um novo modelo que pudesse abarcar essa complexidade de maneira mais ampla e compreensiva.

Segundo Moura Castro (1997), o estudo do humano é complexo pois:

“(...) o processo de observação pode ser de caráter externo e também introspectivo; há grandes riscos de subjetividade em todo processo (...) Tudo isto não deve ser empecilho intransponível à pesquisa, haja vista que a metodologia tem como objetivo ajudar a compreensão, nos mais amplos termos” (p.48).

Diante das complexidades inerentes ao estudo do ser humano, a fenomenologia se insere como uma metodologia que possibilita a compreensão dos fenômenos desvinculada das relações de causa e efeito. A escola de pensamento contemporânea denominada Fenomenologia tem como precursor o filósofo alemão Franz Brentano, mas foi o filósofo Edmund Hurssel quem formulou as principais linhas dessa abordagem (Coltro, 2000).

A partir de Hurssel, a Fenomenologia passou a constituir um método de compreender os fenômenos. Para o autor, estes se referem à realidade que se manifesta por si mesma (França, 1978).

Hurssel (1992) afirma que, em seu percurso de desenvolvimento, a Fenomenologia se apresenta de uma maneira dupla: a Fenomenologia psicológica, que deverá servir como ciência fundamental para a Psicologia, e a Fenomenologia transcendental, ligada à Filosofia. Segundo Giorgi e Sousa (2010), o objeto de estudo da psicologia fenomenológica é a vivência intencional. Para compreender este objeto, é fundamental o entendimento do conceito de intencionalidade. Hurssel adotou o termo de Brentano, propondo alterações e desenvolvendoo, definindo intencionalidade como característica fundamental da consciência. Isto significa dizer que a consciência é sempre consciência de alguma coisa, independente do ato que tal consciência estabelece. Atos de consciência, tais como percepção, imaginação, recordação são intencionais, pois se dirigem a um objeto: o objeto intencional (Giorgi \& Sousa, 2010).

Segundo Giorgi e Sousa (2010), Hurssel afirma que a consciência possui igualmente elementos reais - que estão em um registro empírico - e elementos ideais que, com sua dimensão de sentido, transcendem a contingência empírica temporal e espacial. É a componente intencional da consciência que traz seu objeto de estudo para a dimensão do sentido e do significado.

Em uma perspectiva husserliana, ato de consciência e objeto intencional correspondentes não podem ser analisados separadamente, pois ambos não podem ser compreendidos separadamente, uma vez que mesmo quando o objeto deixa de existir, a consciência intencional é 
capaz de produzir sentidos sobre os objetos não existentes. A investigação fenomenológica deve considerar o ato subjetivo intencional, como por exemplo a percepção, e o objeto a que o ato de consciência se dirigiu, enquanto objeto percebido (Giorgi \& Sousa, 2010).

A ciência, a vida cotidiana e o senso comum concebem os objetos do mundo através da atitude natural, implicando em uma compreensão de mundo que independe da consciência, que precede o sujeito e está sempre presente, factualmente dado (Hurssel, 1992). Uma vez que o objetivo da Fenomenologia psicológica está em alcançar a essência das vivências intencionais, o método de investigação deve suspender os pressupostos inerentes à visão de mundo da atitude natural (Giorgi \& Sousa, 2010).

A redução apresenta-se como um dispositivo metodológico característico do referencial fenomenológico, que implica em um processo e uma atitude a ser exercitada durante todos os momentos do percurso de investigação. Tal atitude permite ao pesquisador o delineamento da essência do fenômeno, seja este um objeto, uma percepção ou uma situação vivida da maneira como este aparece à consciência, identificando suas características fundamentais (Giorgi \& Sousa, 2010).

No âmbito da Psicologia Fenomenológica, tal processo tem como finalidade alcançar sínteses de significados psicológicos (Giorgi \& Sousa, 2010). A redução, ou epoché é caracterizada pela busca da essência do fenômeno, livre de quaisquer elementos culturais e pessoais (Coltro, 2000).

Segundo Giorgi e Sousa (2010) o processo de redução se refere a uma abstenção da atitude natural e dogmática sobre a realidade, o que implica em uma postura do pesquisador de se manter centrado na correlação entre objeto da experiência e na experiência de tal objeto, suspendendo o enviesamento da atitude natural. Os autores ressaltam que a importância da redução é a de permitir abordar, primeiramente, o fenômeno como ele se apresenta, antes que este seja relacionado com experiências similares ou conceitos relacionados, obtidos previamente.

Não existe um método ou procedimento ortodoxo que possa ser assegurado, mantido e reproduzido como método fenomenológico, mas uma postura fenomenológica diante do que será estudado (Sanders, 1982). Essa postura é caracterizada como uma atitude de abertura, que ocorre quando o pesquisador se desfaz dos conceitos apriorísticos de causalidade e explicação ao entrar em contato com o fenômeno, no esforço de compreender o que se mostra (Masini, 1989).

Pode-se dizer que um método é fenomenológico quando seu olhar se detém nos fenômenos a serem estudados, visando esclarecer de maneira cada vez mais diferenciada, o que se mostra por si mesmo ao pesquisador (Boss, 1977). Assim, a reflexão fenomenológica é 
voltada para a experiência, da maneira como ela se manifesta, sem ser precedida por preconceitos, explicações ou teorias.

\subsection{Material}

Giorgi e Sousa (2010), apontam que “os dados 'brutos' de uma investigação fenomenológica são descrições do mundo da vida, da experiência humana” (p.77 ). No presente estudo, os dados utilizados foram as gravações em vídeo de Encontros Comunitários de Saúde Mental, realizados no espaço Cultural Capela da Universidade de São Paulo campus Ribeirão Preto. Tais vídeos são documentos históricos do Hospital-dia da Faculdade de Medicina da USP- RP, já que constituem um registro dos eventos realizados sob a coordenação de tal instituição. Cada vídeo contém, na íntegra, a filmagem de um Encontro e sua duração é de aproximadamente quatro horas por vídeo. O material foi cedido pelo médico responsável pelo evento, que autorizou a realização deste estudo. Foi realizada a análise de dois registros de vídeo, correspondentes a dois Encontros.

\subsection{Aspectos Éticos}

O presente trabalho é parte integrante de um projeto maior, denominado "Estudo dos Encontros e Grupos Comunitários de Saúde Mental: descrição e avaliação”, Protocolo no 2009.1.2282.59.3., aprovado pelo Comitê de Ética da Faculdade de Filosofia, Ciências e Letras de Ribeirão Preto - USP (Anexo 1)

O presente trabalho se enquadra como análise de documento histórico, ou seja, trata-se da análise do registro de um evento público em que participam de 300 a 400 pessoas. As identidades dos participantes dos eventos foram preservadas, e em nenhum momento tais participantes foram identificados. Nas transcrições, foram utilizados nomes fictícios.

\subsection{Percurso de análise}

O delineamento das fases que foram percorridas para o desvelamento do fenômeno é descrito a seguir. É importante ressaltar que, na pesquisa fenomenológica, as fases não são totalmente distintas e separadas, pois o pesquisador habita no mundo do fenômeno estudado. Nesse percurso há uma flexibilidade, característica desta metodologia, que emerge durante o processo (Boemer, 1994). 
Nesse contexto, o presente trabalho seguiu a estrutura proposta por Martins e Bicudo (1989). Os autores buscaram sistematizar um método através do qual fosse possível acessar o mundo vivido através da fundamentação teórica da fenomenologia.

Em tal estrutura metodológica, a análise se baseia em descrições de depoimentos, relatos ou entrevistas sobre experiências vividas, relacionados a um determinado fenômeno, através de quatro momentos. Em todos os momentos é imprescindível que o pesquisador assuma a atitude fenomenológica e realize a redução citada anteriormente.

Inicialmente, foi realizada a transcrição dos registros em vídeo do ECSM e a primeira versão da transcrição foi submetida à apreciação da orientadora e do grupo de pesquisa da mesma. A partir daí decidimos transcrever na íntegra as falas dos participantes focalizados pelo vídeo, bem como seus gestos e expressões significativas para a apreensão das interações focalizadas pela câmera.

Foram registrados gestos, expressões, risos, movimentos que apontavam para alguém ou algum lugar, movimentação no palco, apertos de mãos, abraços e entrega dos microfones. Para auxiliar na compreensão da transcrição, foi construído um quadro de recursos gráficos utilizados na transcrição e seus respectivos significados, que pode ser visualizado abaixo.

Quadro 1 - Recursos gráficos utilizados na transcrição dos grupos e os respectivos significados

\begin{tabular}{|c|c|}
\hline Recurso Gráfico & Elemento Correspondente \\
\hline Preto & Discurso do participante \\
\hline$\frac{\text { Itálico sublinhado }}{2}$ & $\frac{\text { Palavra ou expressão dita pelo participante com }}{\text { ênfase }}$ \\
\hline (Negrito) & Gestos e ações individuais (singular) ou \\
coletivas (plural)
\end{tabular}


O primeiro momento do percurso de análise corresponde à leitura das transcrições, a fim de alcançar um sentido do todo, ou seja, uma compreensão geral da linguagem dos participantes. Nesse momento o pesquisador deve buscar uma compreensão da linguagem da transcrição sem nenhuma interpretação do que está exposto no material, pois este servirá de base para o próximo momento.

O segundo momento é a discriminação de unidades significativas, que deve ser feita com base em uma perspectiva psicológica e focada no fenômeno pesquisado. O pesquisador, após ter apreendido o sentido do todo, retoma a leitura do texto - quantas vezes forem necessárias - com o objetivo de identificar as unidades significativas.

Vale ressaltar que as unidades de significado não existem prontas no texto, mas são identificadas em relação à perspectiva do pesquisador, assim como a realidade psicológica não está pronta no mundo e precisa ser constituída pelo psicólogo (Holanda, 2002). Estas unidades são discriminadas a partir das descrições dos participantes do estudo, uma vez que o pesquisador assume a atitude fenomenológica, tendo em mente a questão norteadora do estudo e emergem quando se percebe uma mudança psicologicamente sensível de significado da situação para o participante.

O terceiro momento é a transformação das expressões cotidianas em linguagem psicológica, que se dá através de um processo de reflexão e variação imaginativa. Essa transformação é necessária, pois o pesquisador deseja desvelar os sentidos múltiplos presentes, ocultos na fala ingênua dos participantes.

Depois de delineadas as unidades significativas, o pesquisador deve expressar o sentido psicológico nelas contido. Assim, a linguagem natural, encontrada no mundo vivido é transformada em linguagem psicológica, mantendo sempre a ênfase no fenômeno em estudo.

No quarto e último momento, o pesquisador deve reagrupar as unidades significativas transformadas anteriormente, buscando sintetizá-las em uma declaração consistente da significação psicológica referente ao fenômeno observado. Essa síntese é denominada estrutura da experiência, que deve ser então comunicada a outros pesquisadores com o objetivo de confirmação ou crítica.

A estrutura desvelada durante o percurso acima descrito remeteu, aos olhos da pesquisadora, ao pensamento do filósofo Martin Heidegger a respeito da compreensão do Ser e do Cuidado, que aponta para uma possibilidade de atitude diante do outro, de si mesmo e da saúde mental. A partir dessa observação foi realizado um diálogo entre as características essenciais do fenômeno e alguns conceitos da filosofia de Martin Heidegger, com o intuito de enriquecer a reflexão acerca das possibilidades do ECSM na área da saúde mental. 


\section{ANÁLISE DO CORPUS}

\subsection{Descrição do Encontro}

Por se tratar de uma ação inovadora no campo da saúde mental, é importante fazer uma breve descrição, baseada nas transcrições do vídeo, para favorecer a familiaridade do leitor com esta prática. Então, a partir das convergências observadas nas gravações em vídeo foi possível perceber um formato através do qual o evento se dá.

Como mencionado anteriormente, participam do evento usuários dos serviços de saúde mental do município e da região, ex-usuários, familiares, estudantes, profissionais de saúde e pessoas da comunidade. Foi possível compreender que por pessoas da comunidade deve-se entender que o evento é aberto para qualquer pessoa interessada em participar dele, seja ela ligada ou não a algum serviço de saúde.

O Encontro se desenvolve em torno de depoimentos organizados em mesas redondas ou através da contribuição espontânea dos demais participantes, constituindo um grande grupo, cuja tarefa segue o tema das mesas redondas. Parte dos depoimentos está associada com experiências relacionadas ao contato com a música e a literatura. Nesse sentido, algumas exposições artísticas são apresentadas no evento, com o objetivo de promover o diálogo acerca de questões ligadas ao tema proposto para o ano. Muitos dos convidados para dar os depoimentos no Encontro Anual são pessoas que participaram de encontros menores.

"Ao longo desse ano fizemos diversos encontros normalmente nas terças-feiras no hospital-dia e mais recentemente ampliamos esses encontros pra alguns encontros nos sábados de forma que, ao longo desse ano, em várias oportunidades, em muitas oportunidades, a gente se encontrou pra conversar. Conversar sobre as experiências que cada um vai vivendo no dia-a-dia e como cada um de nós vai aprendendo, vai conquistando, é... a própria saúde mental”. Ronaldo, psiquiatra e organizador do evento, ECSM 2.

“É um trabalho de um ano em que vão sendo feitos vários grupos e a minha impressão é que se consegue formar pequenas comunidades. $\mathrm{Na}$ idéia de comunidade como com-unidade. Então a gente encontra uma unidade entre as pessoas. Porque a gente tá falando do que é humano, do que é a pessoa, do quê que essas pessoas têm no cotidiano e como que elas podem enfrentar esse cotidiano”. Janaína, docente do curso de Psicologia da USP ECSM 2. 
Os trechos acima ilustram a característica do ECSM de ser resultado de um trabalho feito durante todo o ano, em busca de construir um espaço de conversa e troca de experiências entre os participantes. Ilustram, ainda, como os organizadores percebem e esperam que essa troca de experiências possa ser valiosa para as pessoas, e que as ajude a lidar com suas vidas, conquistando sua saúde mental.

Em cada mesa, os participantes -convidados previamente pelos organizadores do evento - assumem papéis diferenciados. Tais mesas são compostas pelas mesmas pessoas a que se destina o encontro: usuários, ex-usuários, familiares, estudantes, profissionais de saúde e pessoas da comunidade.

“Aqui vão estar falando pessoas que já se trataram ou estão em tratamento psiquiátrico, familiares, profissionais, estudantes”. Ronaldo, psiquiatra e organizador do evento ECSM 2.

Nas mesas as pessoas se organizam em coordenadores (um por mesa, que apresenta o tema, concede a palavra para os depoentes e limita o tempo de fala de cada um), depoentes (de número variado, trazem depoimentos acerca do subtema estabelecido para a mesa da qual participam) e debatedores (um por mesa, que têm a tarefa de fazer o fechamento da mesa, falando sobre o tema, retomando ou sintetizando as falas anteriores). Os coordenadores e debatedores são profissionais de saúde, enquanto os depoentes têm uma composição variada, que contempla todas as categorias de participantes do evento.

"Segundo as instruções que o Ronaldo me passou a idéia agora(...)pra cada relator, pra cada pessoa que vai apresentar nós vamos destinar 5 minutos, pra que possa fazer a sua apresentação, os seus comentários, seus relatos e em seguida o Ronaldo vai abrir pra plateia e depois a Marisa falaria mais, em torno de dez minutos. Ainda assim nós temos uma hora destinada a essa mesa, então nós vamos ter tempo pra um debate com toda a plateia. Ok? Então na função de coordenador as vezes eu vo tá sendo um chato só pra lembrar quando estiver próximo dos cinco minutos, mas eu acredito que a gente tá muito descontraído, muito a vontade aqui pra poder administrar a uma hora que a gente tem. Tá bom? Vamos começar com Marlene.?" Henrique, psiquiatra e coordenador da mesa redonda ECSM 2.

No trecho acima, o coordenador descreve seu papel na mesa, enumerando as funções que desempenhará, prioritaraimente de regulação e organização dos depoimentos. Todos os depoentes têm o mesmo tempo para se apresentar e depois é aberto um espaço para que a plateia se manifeste acerca do tema abordado na mesa. 
Já os debatedores têm a função de fazer um fechamento da mesa retomando e relacionando as falas dos depoentes. As falas de dois debatedores estão destacadas abaixo.

“É difícil ser a última a falar porque muitas das coisas que eu já tinha pensado já foram ditas e eu tenho a tarefa de tentar costurar um pouco a fala das pessoas e juntar com o que eu tinha pensado." Marisa, psicóloga, debatedora ECSM 2.

"Bom, eu vim aqui como debatedora pra misturar todos os depoimentos e também como profissional, que eu sou da área da saúde.” Beatriz, psicanalista, debatedora ECSM2

Em duas mesas - a de abertura e a de encerramento - nota-se uma organização diferenciada e uma composição mais homogênea, contando com a participação de docentes e chefes e profissionais de saúde da USP. Essas mesas têm um conteúdo específico, diferente das que são centradas em temas da saúde mental e nos depoimentos das pessoas.

A mesa de abertura é composta por pessoas de instituições envolvidas com a organização do evento, tem um tempo menor que as demais mesas e é reservada para que os profissionais de saúde falem sobre como o evento acontecerá e quais atividades estão programadas. Freqüentemente os participantes dessa mesa expressam seu desejo de que todos participem do encontro com depoimentos e sugestões, e aproveitem a riqueza da partilha de experiências.

A mesa de encerramento, como o nome já anuncia, também tem um tempo menor que as demais centradas em depoimentos, e é voltada para retomar os temas discutidos durante a manhã, numa tentativa de produzir uma síntese do que foi feito durante o evento. Nessa mesa os participantes são convidados para os demais encontros, semanais e mensais, e também há um momento de agradecimento pela participação de todos.

Além das atividades programadas previamente nas mesas, é parte integrante da estrutura do ECSM um momento de fala espontânea, quando a plateia é convidada a contribuir com depoimentos acerca do tema do evento.

"Mas eu queria perguntar pra vocês, nessa mesa a gente tá pensando nessa encrenca que é viver com as pessoas diferentes, viver e poder transformar isso numa coisa positiva pra nossa vida. Eu pergunto se quando vocês estavam ouvindo as pessoas, se alguém se lembrou de alguma coisa que... que tem vivido nos últimos dias, alguém se lembrou de alguma experiência que gostaria também de contar rapidamente, se alguém se lembrou de alguma experiência que tá vivendo nesses últimos dias de superação de dificuldades de relacionamento, alguma coisa assim, que queira rapidamente contar 
alguma experiência. (Ronaldo percorre a plateia com os olhos) Aqui". Ronaldo psiquiatra e organizador do evento.

"Meu nome é Lígia. Eu sou portadora de esquizofrenia, e eu tenho escolaridade universitária já e tava procurando emprego por muito tempo. Apesar de que eu tenho nível superior tava muito difícil passar nas entrevistas, aí eu recorri a concurso público. Foi a minha chance. Faz pouco mais de dois meses que eu tô na prefeitura, tô conseguindo trabalhar, me superando, cada dia, me esforçando. Eu até ajudo minha mãe em casa, na parte financeira né? E eu acho que o doente mental não tem que falar "eu não sou capaz, eu não consigo", eu conheço gente que fala isso, que não muda de ideia, que é aposentado por invalidez, e eu acho que não é por aí. Eu acho que Deus deu saúde pras pessoas e cabe a elas saber aproveitar da melhor forma." Lígia, usuária.

Nesse momento, o evento funciona como um grande grupo, no qual as pessoas são convidadas a falar sobre suas experiências relacionadas ao tema em questão.

$\mathrm{Na}$ abertura, no fechamento e entre as atividades acima descritas, o evento proporciona apresentações artísticas variadas, feitas por profissionais de saúde, corais da cidade e da faculdade e grupos ligados a usuários ou ex-usuários do serviço.

"Nós vamos ter aqui algumas mesas redondas, vamos ter apresentações de música, vamos ter muita coisa bonita acontecendo do lado de cá (aponta para atrás da mesa em que está sentado) mas também queremos que muita coisa bonita aconteça do lado (gesticula em direção a platéia) deste lado, com vocês podendo falar, participar, podendo tá junto com a gente nesse trabalho." Ronaldo, psiquiatra e organizador do evento.

É importante ressaltar a condição do evento estar em construção. Em diversos momentos do registro é possível perceber a abertura dos organizadores do evento para sugestões dos participantes. Em um dos eventos estudados pode-se perceber o desenvolvimento de pesquisas para conhecer e aprimorar o ECSM.

"Então eu queria contar pra quê que a gente tá fazendo essa pesquisa né? Esse encontro ele tem mais de dez anos. Ele não é feito por algumas pessoas ele é feito a muitas mãos, né? E essa pesquisa tem por objetivo avaliar e saber a opinião de vocês participantes, tendo por finalidade organizar as próximas atividades dos próximos anos e dos próximos meses”. Laís, estudante e colaboradora do evento.

"Última coisa que queria dizer é que nós estamos num processo de construção. Até que isso é evidente porque acabamos de colocar o nome (Encontro Comunitário de Saúde Mental), nós estamos 
desenvolvendo esse encontro. Então sinceramente queria pedir que todos os que estão aqui continuem nos ajudando e se tornando cada vez mais parceiros dessa história que tá em desenvolvimento, né? Quem acompanha os encontros desde o primeiro sabe que cada an, alguma coisa muito significativa muda. Na organização, no jeito da gente trabalhar. E isso acontece graças a pessoas que vão se tornando parceiras. Então esse é o meu último pedido que eu queria fazer, de que vocês continuem se tornando parceiros, tragam sugestões, tragam críticas, porque nos interessa trabalhar cada vez mais com mais pessoas.” Ronaldo, organizador do evento

A partir dos trechos acima citados, é possível perceber que o Encontro se dá seguindo um formato organizado e identificável, mas também é possível perceber que parte desse formato é seu caráter de abertura a novas incorporações.

\subsection{Estrutura do Encontro}

O percurso de análise do fenômeno foi realizado tendo em mente a questão norteadora: “Qual é o sentido do Encontro Comunitário de Saúde Mental, desvelado a partir das interações de seus participantes durante o evento?”. Uma vez que se trata de análise de vídeo, não houve um questionamento direto aos participantes sobre o sentido do Encontro. Assim, para apreender o sentido do fenômeno foram utilizados os relatos que os participantes faziam espontaneamente durante o evento, e o que este representava para eles. As unidades de significado construídas nesse processo deram origem à seguinte estrutura do fenômeno, a saber: a) Partilha, b) Valorização das pessoas, c) Valorização das Relações, d) Reconhecimento de Semelhanças, e) Aprendizado, f) Experiência Comovente, g) Satisfação e h) Gratidão.

\section{a) Partilha}

Nas mesas redondas e na participação da plateia, o conteúdo dos depoimentos é baseado, na maioria das vezes, na vida das pessoas que compartilham com os presentes experiências significativas para elas.

"Nós tamo aqui pra construir hoje, agora, nessa manhã, um momento em que a gente vai compartilhar um pouco da nossa vida” Ronaldo, psiquiatra e organizador do evento, ECSM2 
O organizador comenta sobre a proposta do evento, estruturada em torno da possibilidade de todos os participantes compartilharem suas experiências pessoais acerca de temas relacionados à saúde mental, e de se beneficiarem com essa troca.

"Eu sou uma ex-paciente do HD. Eu tenho um transtorno de personalidade borderline. Eu queria no meu... frisar, não adianta tratar somente o paciente. Tem que tratar a família inteira. Porque a casa fica doente. A casa fica completamente doente, as pessoas não se encontram, elas não se conversam, elas se inibe e elas não conseguem entender... a doença. Por isso que tem que ter muita ajuda da família na doença da saúde mental. As pessoas, elas não são tão ruins ao ponto de não entender. É que elas não conseguem. Elas não conseguem, é muito difícil. Eu, numa psicoterapia que eu tive em grupo familiar, eu percebi que o meu filho tava doente porque ele já não tava mais tomando banho e eu percebi ele sujo. Ele já não tava mais tomando banho, não tava conversando, não tava indo na escola, e foi aonde eu pedi ajuda pros psiquiatra, pros psicólogo, e a gente começou a tratar a família, e foi muito $100 \%$. Não é fácil, é muito difícil , mas foi uma satisfação imensa.” Milena, ex-usuária.

A participante, a partir de sua experiência pessoal, enfatiza a importância do serviço de saúde mental se estender para a família, pois as relações familiares ficam prejudicadas pela falta de compreensão em relação ao sofrimento mental. Milena partilha com os presentes uma experiência de compreensão que teve a partir de sessões de terapia em grupo, que a motivou a pedir ajuda para sua própria família. Ela reconhece as dificuldades do tratamento, mas também a ajuda recebida.

"E outra coisa também que ajudou muito é, no caso assim, que, na minha família é eu, meu pai, minha mãe, e nós somos em 3 filhos, e eu sou a portadora da doença. E meus irmãos, por não entender na minha infância, eles também me discriminavam e isso é muito ruim, a discriminação da doença, que é a discriminação por não conhecer. Então eles achava que eu era uma retardada, eles não deixava eu sair com eles, eles não queria eu com eles, por que? Porque eu estava em crise e quando eu estava em crise eu passava uma forma ruim, então as pessoas às vezes precisam conhecer a nossa forma boa, o nosso lado bom, porque nós temos um lado bom.” Teresa, usuária, ECSM1

A participante partilha uma experiência de ser rejeitada pelos irmãos, que a discriminavam por não compreender o que acontecia com ela. Ela ressalta que todas as pessoas têm “uma forma boa”(sic), mesmo que tenham momentos difíceis e de crise, e que é importante essa forma ser conhecida pelo outro. 
"No primeiro momento fui recebido de braços abertos, muito, muito bem, por eles todos, do hospital-dia, e dali começou o tratamento. E não só na minha esposa. Eu vi que eu também tava doente. Porque eu já não tinha cabeça pra mais nada e eu tenho que trabalhar, mas a cabeça não funcionava. Que eu tinha a minha mulher, muito doente, que eu tinha que ficar em casa. Passou no final pro hospital-dia, e eu toda as quarta-feira ia participar das reunião de família. Que é uma das melhores coisas que eu já vi. Em todo lugar que eu passei não tinha isso. E lá no hospital-dia tem. Pra mim poder falar as minhas coisa, minha situação, e ver muita gente que tem o mesmo problema que eu. Não era eu sozinho que tinha aquele problema, ali tinha pai, ali tinha irmão, ali tinha marido também, que são poucos os maridos né? Mas tinham. Tinha mulher de paciente. Então eu pude sentir e falar dos... dos meus defeito, das minhas angústias e da minha compreensão com a minha mulher. E hoje eu venci. Hoje minha mulher tá aí no auditório, forte, bonita (olha para a esposa e faz um gesto de apontamento na direção dela, sorrindo) E um abraço pra minha mulher.” Adriano, familiar, ECSM1

O participante partilha sua experiência de se perceber em sofrimento e precisando de ajuda quando foi procurar ajuda para sua esposa. Ele se refere ao grupo familiar promovido pelo hospital-dia com muita satisfação e destaca a importância de também ser ouvido em suas dificuldades. Ele partilha que atualmente tanto ele quanto a esposa estão bem.

"Uma historinha bem curta pra vocês imaginar mais ou menos é.. o que que é o borderline. E a depressão também. Eu trabalhava em dois emprego, e eu vim parar aqui porque eu queria matar a minha chefe. Ó. Matar a chefe. É... também quis pegar o Dr. Rodrigo. Armei um soco pra ele. Fácil hein? Eu em tratamento e eu ia bater nele. Quando aconteceu no meu trabalho de eu enforcar essa, essa chefe minha, uma senhora olhou pra mim e falou procura ajuda. Eu pensei, pra quê isso? Não tô loca! Não. Isso foi no ano passado em outubro. Não, eu não sou louca, por quê que eu vou procurar? Errr. De repente eu fiquei em casa e pensei assim ah, acho que eu vou. Vou procurar mesmo. Ah, todo mundo fica falando, eu vou procurar. E eu cheguei aqui. Eu quis ajuda. Eu sempre odiei artesanato ou qualquer coisa do tipo. Principalmente roupa colorida. Só preto eu gostava. Que aconteceu? Isso aqui (mostra um objeto que parece ser uma flor feita de artesanato) mudou a minha vida no primeiro dia de HD. Isso são balinhas de goma. E eu me emociono porque a pessoa que me ensinou isso daqui me disse que não gostava de mim e eu fui fazer, eu achei interessante, eu achei tão, tão, assim, gente, bala de goma virar flores! Vira muito mais que flores! (coloca o microfone sobre a mesa e pega do chão um vaso cheio de flores iguais aquela) Colore a vida" (seus olhos se enchem de lágrimas.) Isabela, usuária. 
Isabela partilha sua experiência de sofrimento emocional e sua dificuldade em aceitar ajuda. Ela conta o momento em que decidiu procurar ajuda, e as transformações que percebeu em si mesma e em sua vida após vivenciar esse processo, pois no serviço ela encontrou a possibilidade de fazer coisas belas e de estabelecer novos vínculos.

"Então gente, esse é um vídeo, somos convidados pra pensar sobre o assunto... Na verdade eu trouxe mais imagens, experiências... Não consegui olhar muito pra mim, que eu acho difícil você olhar pra você e pra sua história e pensar sobre as coisas que marcaram e às vezes até expor isso, mas também foi uma experiência visual que me marcou. Acho que ela fala do diferente, só que entre passarinhos né?” Amanda, residente de Psiquiatria.

A participante mostra que o Encontro permite a partilha das dificuldades, inclusive as dos profissionais de saúde de pensarem sobre as próprias experiências marcantes e falarem sobre elas diante de outras pessoas. Porém essa dificuldade de falar não é excludente da experiência do Encontro, pois diante de sua dificuldade, a participante opta por partilhar um vídeo que tinha sido significativo para ela.

O evento acontece construindo um lugar onde é possível falar e ouvir sobre dificuldades, necessidades e recursos para a construção da saúde mental, no qual são compartilhados pensamentos, sentimentos e vivências dolorosas e de superação, e onde as falas são valorizadas como algo importante para a vida de todos aqueles que as ouvem.

\section{b) Valorização da pessoa}

No ECSM os participantes são vistos como pessoas que têm algo valioso para oferecer e compartilhar. As experiências, reflexões e sentimentos de cada participante têm um lugar para serem revelados, ouvidos e respeitados durante o evento.

"eu fiz questão de apresentá-los como os nossos psiquiatras, porque eu acho que esses, isso que a gente quer poder compartilhar aqui hoje. Essa felicidade de poder ver os nossos pacientes nos ensinando $e$ poder ver os nossos psiquiatras cantando" Ronaldo, psiquiatra e organizador do evento ECMS 1

O psiquiatra se refere, com satisfação, a uma possibilidade construída pelo evento, de encontrar as pessoas do serviço de saúde mental de uma maneira diferente da cotidiana. 
"Nas nossas relações, que a gente possa pensar um pouco mais sobre isso. Que as pessoas, mesmo com todas as suas limitações, elas têm a nos acrescentar, elas têm a nos ensinar, e elas têm a nos mostrar". Viviane, usuária.

No trecho acima, a usuária expressa seu desejo de aprendizado através de suas relações, e propõe uma reflexão aos demais participantes a partir da valorização de cada pessoa, reconhecendo o outro como alguém que pode contribuir para a saúde mental de todos, com seus potenciais e seus limites.

O Encontro promove um momento em que seus participantes podem ser reconhecidos como pessoas que têm algo a oferecer a todos, desconstruindo os lugares sociais frequentemente associados aos usuários do serviço, seus familiares e profissionais de saúde mental. A diferença entre as pessoas não são vistas como um impedimento em sua possibilidade de contribuir com os demais. A postura dos participantes da plateia e as atividades desenvolvidas no palco evidenciam uma atitude de respeito e acolhimento frente às pessoas que estão compartilhando pensamentos, sentimentos e experiências.

\section{c) Valorização das Relações}

O evento promove uma forma de encontro entre as pessoas que valoriza a qualidade das relações. Em seus depoimentos, os participantes do ECSM frequentemente compartilham momentos em que o relacionamento com o outro foi significativo em suas vidas.

"E aí pra terminar eu acho que eu queria ter uma fala de valorização desse evento. A gente, eu partilho da ideia de que a família é muito importante, mas eu também partilho da ideia que a nossa vida oferece oportunidades de encontro a todo momento. Acho que são as nossas redes sociais. Os nossos amigos, os nossos colegas, os serviços de saúde, acho que um acontecimento como esse. E acho que o convite é a gente também se abrir a esses outros encontros porque existem relações de muita lealdade, de muita confiança, de muito respeito." Natália, docente de psicologia.

A participante encerra seu depoimento valorizando o evento como um facilitador de encontros entre as pessoas. Ela afirma que embora reconheça a importância das relações familiares, outras relações em outros contextos podem ser muito boas para a vida das pessoas.

"Por fim gente, eu gostaria de ler um trecho de Rubem Alves que eu acredito que se relaciona um pouco com essa história e eu gosto 
muito. 'O que as pessoas mais desejam é alguém que as escute de maneira calma e tranquila, em silêncio. Sem dar conselhos. Sem que digam se eu fosse você. A gente ama não é a pessoa que fala bonito, é a pessoa que escuta bonito, a fala só é bonita quando ela nasce de uma longa e silenciosa escuta. É na escuta que o amor começa. E é na não escuta que ele termina'”. Valentina, agente comunitária.

A participante cita uma obra que fala sobre a importância da experiência da escuta para a construção de relações interpessoais significativas na vida de todas as pessoas. No trecho citado o autor ressalta a escuta como uma qualidade da relação interpessoal que é essencial para a vivência do amor.

"Eu queria contar uma experiência que aconteceu comigo, eu já tava na residência de psiquiatria. Eu acompanhei um paciente que tava fazendo tratamento, que tava em crise, e teve um dia que eu percebi que eu tava... na minha cabeça eu achava que eu ia aprender sobre saúde mental somente com os professores, com os profissionais da área da saúde mental. E aí um dia eu me dei conta que eu tava aprendendo muito com aquele paciente. Que apesar de ele tá em crise, de ele tá muito doente naquele momento e de eu estar indo pra ajudá-lo eu também tava conseguindo aprender com esse paciente. E o que eu tava aprendendo é que esse paciente, ele tinha uma abertura muito grande pra ouvir o que as outras pessoas tinham pra dizer pra ele. Principalmente sobre o jeito dele conviver com as pessoas, o jeito dele agir, né? E aí eu percebi que essa pessoa, essa vontade que essa pessoa tinha de entende, $r$ o jeito que ela era e essa abertura pra ouvir os comentários, pra tentar mudar, pra tentar melhorar, era um lado muito saudável dessa pessoa. E aí eu percebi que apesar de ela estar doente ela também tinha esse lado saudável. E eu percebi também que, assim, se a gente rotula as pessoas muitas vezes a gente se fecha $e$ não consegue aprender, não consegue ver a pessoa por inteiro, $e$ aprender alguma coisa com essa pessoa, vendo todos os lados dela. E eu percebi que assim, eu também percebi outros lados meus. Que além de tá ali como médica pra cuidar, eu também tinha um lado aprendiz que tava conseguindo aprender com esse paciente."Fabiana, residente de psiquiatria.

A participante relata uma experiência pessoal de relação profissional/paciente, e como esta possibilitou a ela olhar para seu paciente de uma forma mais ampla. A partir dessa abertura, ela foi capaz de compreender de uma maneira diferente a si mesma, ao outro e às pessoas em geral.

"Apareceu outra coisa nova com o meu filho que foi internado no hospital-dia. Ele já saiu, mas eu continuei a ir naqueles grupos comunitários. É uma das coisas que têm me ajudado bastante, que lá 
eu vejo familiares né? Contando experiências que eu tô passando, então eu às vezes vou já com o objetivo de encontrar uma solução. Porque eu passo problemas em casa, e eu já sei que lá eu vou ouvir uma família, vou ouvir um paciente, vou ouvir a equipe falando alguma coisa que vai servir pra que possa me ajudar naquele problema do dia-a-dia. Então isso tá sendo de muita ajuda. E não tem, e não tem um fim, porque os problemas nossos, todo dia aparece diferente, são pessoas diferentes que vem a conviver com a gente... nós mesmos mudamos, amadurecemos né?” Suzana, familiar.

A participante valoriza as relações que se estabelecem nos grupos comunitários, pois entende que a troca de experiências com outras pessoas pode ajudá-la a viver melhor com as dificuldades que enfrenta no cotidiano.

\begin{abstract}
"Eu tenho um filho com esquizofrenia desde os 15 anos. Ele deu muito trabalho e até conseguiu fugir de sete enfermeiros da psiquiatria da Unicamp. E era muito forte, e era muito paparicado pelo pai também, então a gente não fazia os tratamentos muito completos né? E eu estive em quase todos os hospitais do estado de São Paulo, e ele também fugia, aí eu me mudei há 3 anos atrás pra Minas Gerais, São Sebastião do Paraíso. E lá eu encontrei outro estilo de vida, outro ambiente, não tem aquela pressa, aquela impessoalidade que tem em São Paulo, porque o Itapira é um hospital perfeito, mas a gente não pode reclamar de nada, mas o enfermeiro não olha pro paciente, é um robô né? (...). E eu me surpreendia como todo mundo tratava ele muito bem e conversava, não estranhava, em todos os lugares... Então eu tô muito melhor lá e eu perdi o medo de sair na rua com o meu filho né?” Irene, familiar.
\end{abstract}

A participante compartilha a experiência da mudança de cidade como algo transformador em sua vida, pois percebeu na cidade pequena uma disposição para as relações entre as pessoas, que não encontrava em outros ambientes, sentidos por ela como impessoais.

As relações interpessoais são vistas como importantes para a vida e a saúde mental de todos. Os relacionamentos são valorizados como facilitadores de transformações e aprendizado dos envolvidos, provedores de acolhimento e satisfação, mesmo na presença de dificuldades e conflitos.

\title{
d) Reconhecimento de Semelhanças
}

Ao longo do ECSM, os participantes falam sobre suas experiências de vida, emoções, dificuldades e superações vividas. Enquanto falam acerca desses temas, eles comentam sobre 
o caráter comum de suas emoções, como necessidades não apenas particulares, mas necessidades humanas.

“Aqui vão estar falando pessoas que já se trataram ou estão em tratamento psiquiátrico, familiares, profissionais, estudantes. Eu acredito que o que vai cada vez mais ficar claro pra nós é que apesar dessas aparentes diferenças vamos perceber que somos todos muito parecidos, todos com muita vontade de... É... todos com muita vontade de ser feliz. E todos com muita vontade de receber ajuda, de receber apoio, de aprender a se relacionar com o outro.” Ronaldo, psiquiatra.

O organizador do evento aponta para a possibilidade de, durante o Encontro, os participantes reconhecerem muitas semelhanças entre si, apesar das aparentes diferenças. Entre essas semelhanças, o organizador pontua a necessidade de receber ajuda e de aprender a se relacionar com o outro.

"E é com esse intuito que eu tô aqui com vocês, pra juntos a gente poder superar nossas dificuldades, nossas dores e com isso a gente avançar, em busca de uma melhor saúde mental” Jorge, psiquiatra.

O participante partilha sua intenção de, junto aos demais participantes do evento, viver uma experiência de ajuda. Ele se refere a dificuldades, dores e ao desejo de avançar em busca da saúde mental como uma possibilidade comum a todos.

"E eu depois que eu descobri que eu tava doente eu comecei a procurar muito em livros e na internet pra mim poder entender, pra mim poder passar pros meus familiares, pros meus amigos, o que que significava essa doença na minha vida. E tem uma coisa que eu li que fala assim que a doença mental, ela pode acontecer com qualquer pessoa em qualquer hora da vida dela."Carla, usuária e mãe de usuário.

A participante compartilha sua busca por uma compreensão a partir do descobrimento de sua doença e destaca, entre as coisas que leu, sua descoberta de que a “doença mental” é uma possibilidade comum a todas as pessoas.

"Nesse sentido, eu tinha pensado da gente poder pensar nessa condição que vem desde o bebê como ser aberto e necessitado. Então o bebê ele tem os furos que a gente mantém, então eu tenho boca, nariz, olho, pra poder ser alimentada de fora. Pra que eu possa receber algo que é de fora eu preciso, em primeira pessoa, reconhecer a minha fragilidade, a minha pobreza. Então eu preciso reconhecer que como todos vocês aqui contando de sofrimentos, de 
dores, de sentimentos difíceis, de agressividade, que a gente partilha de tudo isso. E a gente precisa fazer encontros que possam nos alimentar e nos levar aí a uma maturidade. É... que nos coloque de novo no caminho né?” Janaína, docente de Psicologia.

A participante compartilha o pensamento que teve ao ouvir os depoimentos. As falas dos demais participantes provocaram nela uma reflexão acerca da condição de abertura, fragilidade e necessidade que todos os seres humanos compartilham, desde bebês. Ela ressalta a importância dos encontros humanos para alimentar tais necessidades e levar ao crescimento dos envolvidos.

\begin{abstract}
"Bom, eu fiquei com essa tarefa difícil né? De fechar essa mesa, e eu vou tentar fazer, acho que foi emocionante e que a gente pôde perceber como que essa experiência da perda... porque acontece com todos nós, não só em família, mas de pessoas muito queridas e próximas. (...)Eu acho que os depoimentos aqui mostraram o quanto que a gente precisa do outro. Seja o outro familiar, seja o outro médico, psicólogo, enfim, mas o quanto que a gente precisa do outro pra superar essas perdas né?” Marcela, psicóloga e debatedora.
\end{abstract}

A debatedora da mesa, após ouvir todos os depoimentos, caracteriza essa escuta como uma experiência emocionante e compartilha sua percepção da vivência da perda e de suas dificuldades como uma condição comum a todas as pessoas. Ela ressalta também a semelhança de todos os participantes em sua necessidade de encontros com o outro para superar as perdas.

\footnotetext{
"Então eu acho que essa questão, quando eu tô escutando tudo isso aqui, eu realmente quero, Ronaldo, te parabenizar, isso aqui é fantástico, eu acho que vocês estão fazendo uma coisa ímpar pela saúde mental nossa (aponta para si mesma) porque não é (aponta para a plateia) é nossa (aponta para si). Nós também temos os nossos momentos psicóticos. Nós também temos momentos de desestruturação total.” Beatriz, psicanalista e debatedora.
}

A participante afirma que o ECSM é uma iniciativa que faz bem a saúde mental de todos os envolvidos e enfatiza o caráter compartilhado da saúde mental, afirmando que os profissionais de saúde também vivem momentos de intenso sofrimento e desestruturação.

De maneira geral, os participantes falam de sofrimento, doença e fragilidade como aspectos humanos a que todas as pessoas estão sujeitas. Apontam necessidades compartilhadas por todos, como por exemplo a necessidade do outro e das relações para a superação das dificuldades e para a construção da saúde mental. 


\title{
e) Aprendizado
}

Os participantes revelam que o ECSM oferece a possibilidade de aprendizado através da escuta dos depoimentos. Os participantes demonstram valorizar esse tipo de aprendizado, que ocorre através da abertura para a troca de experiências com as pessoas. Em seus depoimentos, muitas vezes os participantes compartilham situações que lhes proporcionaram algum aprendizado.

\begin{abstract}
"A gente vêm se encantando muito com esse trabalho porque nele aprendemos muito ouvindo os depoimentos né? Dos colegas, profissionais, pacientes, familiares, e eu acho que essa é uma grande inovação dos encontros que a gente pode ter de saúde mental” Lívia, psicóloga.
\end{abstract}

A participante ressalta a possibilidade de aprendizado a partir da escuta dos participantes como uma inovação do ECSM que pode ser vivida nos encontros de saúde mental.

"E eu acho que, como quando a Lúcia cantou aquela música do Gonzaguinha, eu adoro aquela música, eu sou uma eterna aprendiz. Eu acho que vocês me ensinaram coisas incríveis e eu acho que eu já falei tudo o que eu podia falar. Vou dar a palavra pros depoimentos de vocês porque adorei os depoimentos que vieram da vida real. Não é teoria.” Beatriz, psicanalista.

A participante se identifica com a condição de estar sempre aprendendo, representada pela música apresentada no evento. Ela diz aos demais participantes que eles lhe ensinaram muitas coisas, e valoriza a partilha de experiências de vida.

"Primeiro eu quero agradecer ao Dr. Ronaldo por estar aqui hoje, é... Pra mim é uma experiência nova. Nunca tinha participado de um encontro assim e eu tenho aprendido muito nesta manhã né? E parabenizar a todos (faz um gesto circular com a mão) que se dispuseram a tá aqui, que eu sinto que está sendo uma manhã muito rica para todo mundo.” Larissa, psicanalista.

A participante ressalta a inovação do Encontro e agradece ao organizador por ter sido convidada para estar lá. Ela afirma que aprendeu muito durante o evento e parabeniza a todos os participantes por sua disponibilidade de construírem o ECSM e de o enriquecerem com seus depoimentos. 
"Eu tenho somente que agradecer mesmo e quando eu posso estar sempre vindo aos grupos às terças-feiras, mas é que eu tô assim, minha mãe né? Tá vindo com muita sequência no hospital então não tá tendo jeito de eu participar, mas cada vez que eu venho eu vou embora mais fortalecida e com um aprendizado maior ainda. Então é isso".Viviane, usuária.

A participante revela a maneira como se sente ao participar dos encontros comunitários e comenta seu desejo de frequentar mais assiduamente os encontros às terçasfeiras. Vale ressaltar que esses encontros semanais dão origem ao ECSM.

"Então que cabe a cada um de nós procurar fazer essas mudanças aprendendo no dia-a-dia como aprendemos aqui hoje. Eu penso que hoje, assim, eu aprendi muito, pra garantir eu acho, o ano inteirinho. Assim, eu me emocionei com os depoimentos, teve hora que as lágrimas chegaram a rolar, e aí eu falo 'Não, mas eu não quero chorar'. Quer dizer, as vezes eu ainda travo as minhas emoções, né?” Luciano, usuário.

O participante valoriza a importância do aprendizado diante da intencionalidade de produzir mudanças e comenta que no Encontro ele aprendeu muitas coisas. Ele comenta que até tentou conter sua emoção diante dos depoimentos, mas que não foi possível.

\section{f) Experiência comovente}

Os participantes relatam terem se comovido durante o ECSM. Afirmam que a escuta das experiências compartilhadas no evento despertaram sentimentos e pensamentos. Além disso, comentam a possibilidade de aprender através dessa abertura para as experiências do outro e como essa abertura é capaz de ajudá-los a lidar com o seu dia-a-dia.

"O problema de ficar pro final depois de um monte de gente falando é que desorganiza um pouco aquilo que eu organizei quando tava em casa sozinho, sem ninguém em volta, escrevendo, pensando né? E aí são tantos estímulos que começa a dar vontade de falar outras coisas, você resolve mudar a música no meio, aí começa a criar uma espécie de caos, vai começando a bagunçar tudo porque agora eu não sei o que eu faço com o que eu escrevi. Começa a vir um monte de ideias" William, psicanalista. 
O participante descreve como se sentiu estimulado ao ouvir os depoimentos, que lhe trouxeram novos pensamentos e ideias. Ele relata que esses novos pensamentos transformam o que ele havia planejado falar previamente, quando estava sozinho.

"Bom dia a todos. Eu queria começar agradecendo o Ronaldo pela oportunidade de tá aqui. Eu me sinto privilegiada de ter um tempo de fala em um evento como esse. Assistindo a todas as apresentações, os depoimentos, eu acho que eu já aprendi muito aqui e vivi várias emoções, né? Do riso ao choro." Natália, docente do curso de Psicologia.

A participante fala, com satisfação, que participar do evento ouvindo os depoimentos proporcionou a ela a vivência de diferentes emoções e como ela sente ter aprendido através dessa escuta.

\begin{abstract}
"Eu fiquei muito animada, né? De ver a Gabriela falar sobre esse membro que escuta o outro pedir socorro. Isso nunca aconteceu na minha vida porque eu venho de uma família que nunca se preocupou muito com o meu filho que precisava de ajuda. Então sempre achando que eu tava preocupando demais e só vivendo pra ele. Mas hoje eu vejo que ele tá bem e que eu precisava de enxergar isso. E eu amadureci bastante. Então ser esse membro que escutou esse pedido de ajuda, senão hoje ele não seria a pessoa que ele é. Não ia dar em nada. Então hoje eu fico muito alegre de ser esse membro" Diana, familiar.
\end{abstract}

A participante se emociona positivamente ao participar do encontro, pois se identifica ao ouvir um depoimento de uma das mesas redondas. Ela relata que, ouvindo o depoimento, ela pôde ter um novo olhar a respeito de suas atitudes, o que a deixou feliz consigo mesma.

"Eu tinha até preparado uma série de coisas pra falar, mas de fato fiquei muito comovida e fico pensando na força que esse encontro traz porque a partir desses encontros a gente pode ir também potencializando a força que a gente tem". Janaína, docente do curso de Psicologia.

A participante conta que ouvir os depoimentos lhe provocou emoção e a fez pensar sobre a oportunidade que o evento traz de as pessoas se sentirem potencializadas em sua força. Ela também comenta que a comoção sentida ao participar do Encontro modifica o seu próprio depoimento, comparado ao que havia sido planejado anteriormente. 
"Realmente, é um papel, pra mim é um pouco difícil porque eu estou aqui, ao lado das pessoas que estão falando, e essa emoção que elas falam tá passando por aqui realmente é emocionante essa coragem toda do casal, os depoimentos, eu acho que a gente não poderia ter uma experiência tão rica quanto essa de aprendizado”. Rafaela, coordenadora de mesa, ECSM1

A participante relata sua dificuldade para cumprir seu papel técnico na mesa, uma vez que vivenciar a partilha das experiências dos demais participantes é uma vivência emocionante. Ela admira a coragem do casal que falou sobre o sofrimento vivido após a perda de um filho, e ressalta a riqueza de aprendizado que todos os depoimentos proporcionaram.

Os participantes relatam sua comoção durante o ECSM e valorizam essa experiência como uma oportunidade de aprender, pensar em novas possibilidades de significado e valorizar as potencialidades de cada um.

\section{g) Satisfação}

Os participantes expressam sua satisfação por fazerem parte do ECSM. Eles demonstram seu apreço pela oportunidade de participar e valorizam a iniciativa da construção do ECSM, relatando sua admiração pelo trabalho dos organizadores.

\footnotetext{
"Eu queria partilhar com vocês a minha alegria de tá podendo conversar um pouco nessa abertura. Como o Ronaldo falou, eu participo já há muitos anos acompanhando, admirando, me encantando por esse trabalho que se realiza, com toda uma equipe, que cada vez aumenta mais, de residentes, estagiários, colegas e principalmente dos pacientes, dos usuários do serviço de saúde mental e seus familiares. ” Lívia, psicóloga.
}

É possível perceber que tanto as pessoas que foram pela primeira vez ao Encontro como aquelas que o frequentam há vários anos admiram a forma como o evento é organizado, valorizando a escolha dos temas voltados ao cotidiano das pessoas, e destacando a contribuição de usuários e familiares como valiosa. A escuta dos depoimentos parece afetar os participantes, possibilitando novos pensamentos.

“Acordamos lá de madrugada, são nove horas de carro (suspiro), e o que eu imaginava aqui era, sei lá, passar por mais um momento de conhecimento científico, essas discussões que a gente tem sempre nessa área, mas eu quero agora parabenizar os organizadores do 
evento, por tá trazendo uma questão extremamente importante que é a vida que tá por trás da ciência. Essas pessoas maravilhosas aqui, esses organizadores, esses depoimentos, acho que esse é um referencial que a gente não presencia nos nossos encontros, geralmente voltados apenas para a ciência. Parabéns” Paula, psicóloga, ECSM 1

Algumas vezes os participantes relatam sua surpresa com o formato diferenciado do encontro, em comparação com outros eventos de saúde dos quais já participaram, comumente focados em conhecimento teórico e científico.

"Então eu acho que hoje eu também to, assim, muito feliz de tá aqui, de ouvir todas essas coisas, porque isso vai fazendo com que a gente pense coisas diferentes.” Mariana, docente do curso de Enfermagem.

A possibilidade de falar e ouvir sobre experiências pessoais em um ambiente de respeito e acolhimento parece proporcionar uma vivência agradável às pessoas que participam do Encontro.

\section{h) Gratidão}

Em diferentes contextos, muitos participantes expressam sua gratidão no ECSM, seja pela possibilidade de participar do evento, de falar e ser ouvido, de compartilhar experiências com outras pessoas e aprender com elas, ou pela ajuda recebida através do serviço.

"Bom dia para todos. Primeiramente eu quero agradecer mais uma vez o privilégio de poder tá aqui podendo falar, falar sobre a nossa doença que é ser bipolar. Pois há muito tempo eu sou uma bipolar, desde 13 anos de idade(...)Então eu só tenho mesmo é que agradecer essa oportunidade de tá falando e pedir também, pros médico, que tem muito aqui hoje presente, que observe mais o paciente, que ajude mais o paciente, e procure investigar se ele sozinho tá sofrendo ou se a família também está. Olha, muito obrigada.” Tereza, usuária.

A participante agradece muitas vezes a oportunidade de contar sua história e ser ouvida. Ela se dirige aos médicos presentes compartilhando uma necessidade de que os pacientes e suas famílias sejam observados para que possam receber ajuda em seu sofrimento.

"Bom dia a todos. Muito obrigada ao Dr. Ronaldo por estar participando desta mesa eu e meu filho(...) Bom, aí ele passou pelo dentista, isso foi muito importante, ele passou pelo dentista ele fez 
duas cirurgia na gengiva, e ficou 40 minuto na cadeira do dentista, ele faz a barba sozinho, então hoje, eu me sinto uma mãe muito feliz, porque é uma equipe muito grande de psiquiatria, de psiquiatra, todos que cuida do meu filho. E eu agradeço ao Dr. Ronaldo, à equipe do hospital-dia e todos os psiquiatras. E muito obrigada por tudo." Elisa, familiar.

A participante agradece a oportunidade de fazer parte de uma das mesas do ECSM e de poder compartilhar sua história ao lado de seu filho. Ela revela que teve muitas dificuldades e sofrimento com o adoecimento do filho, e que hoje está em um momento melhor. Ela fala sobre sua felicidade por saber que o filho recebe cuidados de toda a equipe do Hospital-dia, e lhes agradece pelo trabalho realizado lá.

"Então assim, quando tem uma pessoa de fora vendo a situação da gente fica muito mais fácil, como eu vendo a situação da Milena com a filha. Fica fácil da gente amadurecer, a gente pegando a experiência do outro. Então eu tenho muito, mas muito que agradecer ao Dr. Ronaldo e a toda a equipe do hospital-dia porque, hoje assim, eu ajudo muito a Milena, como ajudo muitas pessoas que estão a minha volta." Viviane, usuária, ECSM 2

A participante agradece ao organizador do evento e à equipe do hospital-dia pela ajuda que foi oferecida a ela e que lhe trouxe a possibilidade de, também, ajudar outras pessoas.

"Por isso que eu agradeço tanto as pessoas que tiveram a coragem de vir aqui pensar isso junto. É isso também que eu queria dizer pra vocês porque tantas vezes as pessoas falam assim pra mim 'ah doutor, isso eu não quero nem pensar. Isso eu não quero nem pensar'. E a doença tá aí. A doença tá em a gente não poder pensar, não poder conversar sobre isso que são as experiências da vida" Ronaldo, psiquiatra e organizador do evento.

O organizador do evento agradece a todos os participantes que levaram seus depoimentos, reconhecendo a dificuldade que é falar de experiências muitas vezes dolorosas e ressaltando a importância deste diálogo.

O ECSM torna-se um lugar onde as pessoas agradecem a ajuda recebida pelo serviço de saúde, a oportunidade de dar seus depoimentos contando suas histórias no ECSM, e a possibilidade de ouvir esses depoimentos. 


\subsection{Análise Compreensiva}

O movimento de aproximação e distanciamento do fenômeno, descrito nesse trabalho, desvelou uma estrutura que ultrapassa o reconhecimento do ECSM como apenas mais um grupo desenvolvido em serviços de saúde mental. Isso porque o ECSM traz, em sua essência, não apenas uma técnica, ou seja, um conjunto de ações e instruções para se realizar um evento voltado para a saúde mental. A estrutura se desvelou, fundamentalmente, como uma maneira de se relacionar com o outro.

Essa estrutura, de um evento realizado por um serviço de saúde mental que desvela uma atitude de cuidado diante do outro remete, aos olhos da pesquisadora, ao pensamento do filósofo Martin Heidegger (1927/1986) a respeito da compreensão do Dasein e do Cuidado e aponta para diferentes possibilidades de atitude diante do outro, de si mesmo e da saúde mental.

\section{O ECSM como atitude diante do outro}

O ECSM revela, em sua estrutura, o desenvolvimento de uma ação no âmbito da Saúde Mental, centrada em uma postura diante do outro e do sofrimento mental. Essa postura será descrita a partir das possibilidades de relação estabelecidas entre os participantes e da oportunidade de construção de uma nova compreensão de si mesmo, do outro e da saúde mental, a partir do encontro entre os participantes e da partilha de suas vidas e histórias.

A singularidade do lugar construído pelo ECSM deve ser compreendida à luz do horizonte histórico no qual está inserido. Em uma sociedade na qual o modelo hegemônico de racionalidade impõe uma visão totalitária do conhecimento, a compreensão acerca dos fenômenos humanos é reduzida, pois exclui os saberes subjetivos e baseados na experiência cotidiana. (Giorgi \& Sousa, 2010).

Assim, o ECSM se constitui como um espaço onde é valorizada uma maneira de compreender e se relacionar com o outro que difere do modelo hegemônico, pois nesse espaço são valorizadas a troca de experiências cotidianas e, ainda, os depoimentos singulares de cada participante são acolhidos como algo válido para todos aqueles que compartilham dele. Observa-se que no ECSM as experiências pessoais são as mais frequentemente compartilhadas.

Essa característica do ECSM, de abertura diante das pessoas e da saúde mental que se mostra durante o evento, apresenta-se em consonância com a atitude diante do outro e do 
conhecimento proposta pela Fenomenologia, pois a atitude fenomenológica é uma postura que busca deixar que o fenômeno se mostre, sem tentar enquadrá-lo ou categorizá-lo, para a partir disso conhecê-lo melhor.

Assim, o ECSM se constitui como um espaço que abriga uma oportunidade de diálogo a respeito da saúde mental estruturada em torno da proposta de conversa a respeito das experiências de cada um, sem a imposição de interpretações a partir de conceitos teóricos. Dessa forma, o ECSM contribui para desconstruir compreensões causalistas e deterministas a respeito do ser humano, à medida que propicia a ampliação da compreensão acerca do ser e da saúde mental.

A abertura para o outro, através do encontro e da Partilha de depoimentos pessoais, aponta para a possibilidade de uma nova postura diante do outro, que permite novas formas de relação entre os participantes do evento. Nesse sentido, o ECSM estrutura uma modalidade de ação na área da Saúde Mental que permite a experiência de deixar aparecer o ser dos participantes, a medida que cria um espaço no qual cada um pode se expressar enquanto pessoa, em sua singularidade. Foi possível observar, nos depoimentos dos participantes nas unidades de significado Satisfação, Reconhecimento de Semelhanças, Experiência comovente e Aprendizado, que muitos deles consideram que o encontro contribui para sua saúde mental.

Quando nos voltamos para a Partilha em torno da qual todo o evento se estrutura, percebemos um lugar no qual os participantes têm a oportunidade de se encontrar e se compreender como devir, como ser em movimento dentro de suas histórias de vida, desconstruindo assim a visão de ser humano fechada em diagnósticos.

O conjunto desses elementos que caracterizam o ECSM como um lugar de encontro e expressão dos participantes, através de suas histórias, como movimento e sem imposição de conceitos remete ao conceito de Dasein proposto por Martin Heidegger.

Em sua obra Ser e Tempo, Heidegger (1927/1986) buscou resgatar a questão do ser se concentrando na questão do sentido de ser do homem, que ele diferencia de todos os demais seres. Para o filósofo, o ser não pode ser objetivado, visto que é movimento. Ser é sempre possibilidade de ser, e como possibilidade que ainda não é completamente, ser é sempre vir-aser. Vattimo (2001) explicita essa questão:

"Muito importante para toda a filosofia do século XX é a tese de Heidegger segundo a qual o ser não é, mas acontece, dá-se, é evento” (p.6). 
Segundo Fogel, (1996) desde Descartes, o sujeito foi concebido como um eu interiorizado, senhor de tudo o que existe na natureza e capaz de superar todos os limites e é sobre essa noção que se fundamenta a técnica moderna. De acordo com Ayres (2001), os profissionais de saúde tratam seus pacientes como um núcleo individual e permanente e dessa forma o transformam em mais um objeto no mundo, e assim se tornam menos capazes de compreender possibilidades mais ricas de compreender a construção das identidades e fortalecer o poder transformador dos indivíduos. Dessa forma podemos refletir que o ECSM promove um encontro entre pessoas que possibilita seu deslocamento desse lugar de sujeito fixo para um lugar de ser como acontecimento.

Na analítica do ser, desenvolvida por Heidegger (1927/1986), a noção cartesiana de sujeito será substituída pela noção de abertura do Dasein. Para o filósofo, a palavra sujeito implica em um conceito que leva ao fechamento do ser e está ligada a uma compreensão de mundo determinista e causalista, fundamentando a técnica moderna que visa o controle. Heidegger então substituirá a palavra sujeito pelo termo Dasein, para se referir ao ser humano evitando qualquer tipo de objetivação da essência do homem. De acordo com Michelazzo (1999) Dasein é um termo alemão que Heidegger utiliza para romper com o significado arraigado da palavra existência, que designa o simples dado do mundo sensível. Assim o filósofo caracteriza o modo de existir do homem como ek-sistência, enfatizando o prefixo da palavra para apontar seu sentido de transcendência.

Segundo o filósofo, o Dasein não se encerra em si mesmo, em uma interioridade psíquica, como o sujeito cartesiano. O Dasein é sempre visto em um contexto relacional, em uma relação de co-pertinência com o mundo e com os outros Dasein, ou seja, Dasein é sempre ser-com. É relevante ressaltar que ser-com não se refere à possibilidade ôntica de se estar em companhia de outras pessoas, mas sim à condição ontológica do Dasein de ser originariamente ser-no-mundo-com-o-outro. (Heidegger, 1927/1986).

Falar em Dasein implica em uma compreensão do ser em movimento, aberto e lançado em um mundo do qual ele não tem controle, mas cuja presença carrega a possibilidade total e completa da existência, não passível de objetivação. Assim, Heidegger rompe com a visão dualista de homem, como sujeito soberano da verdade, em oposição aos objetos que ele conhece e controla. Segundo Heidegger (1927/1986), o Dasein é um ente que se diferencia dos demais por ser o único que tem o seu ser como questão. Ter o ser como questão se refere à possibilidade de meditar sobre seu horizonte, questionar-se a respeito de sua existência, fazer planos, decepcionar-se, entre outros. 
No evento, os participantes são valorizados pelo que eles são e pelo que podem oferecer ao outro enquanto pessoas. O ECSM se estrutura a partir da oportunidade dos participantes se mostrarem em seu movimento de ser e através desse compartilhamento, refletirem, se emocionarem e construírem novas compreensões acerca de si mesmos e da saúde mental, como descrito nas unidades estruturais Experiência Comovente e Aprendizado.

Um exemplo dessa possibilidade pode ser observado na fala do participante Luciano (pp 54), na qual ele relata as emoções que viveu durante o evento, ressaltando a importância do aprendizado possibilitado através da partilha dos depoimentos. Ele percebe a si mesmo tentando inibir suas emoções, mas em seu discurso pode-se observar que ele encara essa atitude como algo presente, porém passível de mudança, pois quando declara que "ainda trava suas emoções” (sic), está presente uma condição de vir-a-ser diferente.

Ao favorecer a compreensão do ser como acontecimento, o ECSM ressalta a condição do ser humano como ser aberto a diversas possibilidades, pois não fixa os participantes através de conceitos ou diagnósticos. Ao promover esse olhar, o evento contribui para a desmistificação dos estigmas que acompanham o campo da Saúde Mental.

Essa atitude diante do ser construída pelo ECSM vai na direção oposta das posições hegemônicas de saber e dos modos de produção e cuidado baseados na lógica positivista. Martin Heidegger (1927/1986) afirmou que o modo positivista de pensar, que ultrapassou as ciências naturais e se expandiu para todas as áreas do conhecimento, afetando a vida das pessoas na cotidianidade, levaria a um esvaziamento da existência, pois propiciava o esquecimento do sentido do ser.

Durante o ECSM, é possível perceber que os participantes não são tratados como seres objetivados, uma vez que no evento, através da análise das unidades Partilha, Valorização das Pessoas e Reconhecimento de Semelhanças é ressaltada a compreensão dos mesmos como movimento. Tal compreensão dá condição para que se construa um olhar para si mesmo e para o outro, não a partir de algo que se é e sempre será, mas como um constante vir-a-ser. Essa compreensão de si como movimento pode ser vivida no evento, como pode ser observado em depoimentos como o de Isabella (pp 45).

Em seu depoimento, Isabella revela diferentes movimentos de sua história: a rejeição da oportunidade de ajuda, a aceitação e procura por ajuda, o ódio ao artesanato e o significado de colorir a vida que o artesanato passou a ter para ela. A apresentação e a escuta desse depoimento favorecem o entendimento do humano como cheio de possibilidades, e em constante movimento de vir-a-ser. 
O ECSM ressalta a importância de cada um ser ouvido e valorizado em suas experiências, e ainda, a importância da construção de sentidos a partir das vivências. Nessa perspectiva, todos os participantes do evento se tornam depoentes em potencial, uma vez que todo aquele que vivencia tem conhecimento correspondente a essa vivência. É percebida no evento uma atitude de valorização de cada participante como alguém que possui saberes relevantes, a serem compartilhados com os demais, e o encontro promovido entre essas pessoas é também um ato de construção de si mesmo e da própria saúde mental. Essa valorização de todos se reflete na composição heterogênea das mesas redondas, que conta com a participação de usuários, familiares, estudantes e profissionais de saúde.

Porém, embora o Dasein seja essencialmente abertura para possibilidades de sentido, em indissociável relação com o mundo, Heidegger (1927/1986) afirma que na cotidianidade seu modo mais imediato de se relacionar com os entes se dá através da ocupação, subordinada ao ser-para dos instrumentos. Nesse sentido, Sá et al. (2006) apontam que:

"No caso da época moderna, o Dasein encontra de início a si mesmo como 'sujeito', 'egoidade', 'individualidade', interioridade' em contraposição ao mundo 'exterior' e separado dos outros sujeitos(...)”(pg. 114)

Ao refletir a respeito das possibilidades do ser humano de se compreender e viver como ser aberto e em movimento e de também poder viver como ser objetivado, é possível refletir sobre essas duas possibilidades também na construção do cuidado em saúde, e nesse sentido, podemos compreender o ECSM como um espaço que favorece a vivência da possibilidade de ser aberto, em movimento de vir-a-ser.

Para Heidegger (1927/1986), existir é estar diante da condição de ter que ser e de poder ser, e diante desta questão o Dasein é lançado numa realidade fática, mas livre para escolher apropriar-se dessa tarefa existencial e construir seu sentido ou fugir dessa condição caindo na impessoalidade e na massificação. Ao observarmos as características essenciais do evento, como a Partilha, o Aprendizado e o Reconhecimento de Semelhanças, podemos apontar para a proposta do ECSM como uma ação que pode favorecer aos participantes a vivência de ser-aberto a muitas possibilidades, permitindo o resgate dos sentidos de suas experiências, que por vezes são abafados ou esquecidos na cotidianidade.

Porém, da mesma maneira que o Dasein pode se encontrar aberto a seus sentidos mais próprios ou velado pela impessoalidade da cotidianidade, dentro do movimento dinâmico de ser e vir-a-ser, também no ECSM os participantes podem se apropriar da proposta de 
expressão e encontro com o outro ou podem repetir padrões e esteriótipos presentes no dia-adia. Apesar da proposta do ECSM se constituir em torno da Partilha de experiências, podemos observar, a partir das transcrições, que nem todos os participantes dão depoimentos baseados em experiências pessoais, que permitam o aparecimento do ser em movimento. Ou seja, em alguns dos depoimentos de profissionais de saúde percebemos eventualmente um modo de participar do encontro que se dá através da exposição de teorias e de depoimentos baseados no conhecimento formal.

É possível compreender que é com esta linguagem que os profissionais de saúde estão habituados a contribuir em eventos e serviços de saúde. Por outro lado, observamos em alguns depoimentos, a surpresa de alguns destes profissionais ao perceberem o que o formato do evento proporciona enquanto possibilidade inovadora, de troca de experiências pessoais e da compreensão singular dessas vivências.

Nesse sentido vale ressaltar que o atual modelo de saúde mental, pautado nos princípios da reabilitação psicossocial, requer novas habilidades dos profissionais de saúde, porém a formação destes profissionais se dá em torno dos aspectos técnicos e científicos a respeito de diagnóstico e tratamento de doenças e agravos, sem integrar as necessidades das pessoas à gestão (Ceccim \& Feuerwerker, 2004). Segundo Yasui e Costa-Rosa (2008), a formação dos profissionais de saúde pode ser considerada como um impasse na concretização da Reforma, pois a mudança de paradigma necessária para a implantação do novo modelo assistencial ainda é precária na formação básica dos mesmos, e sofre influência do pensamento positivista.

Assim, é possível considerar que a estrutura do ECSM oferece uma oportunidade transformadora também para os profissionais de saúde, na medida em que eles são convidados a assumir o lugar de participantes, a dar seu depoimento a respeito de suas vivências, e a ouvir o outro em uma perspectiva de abertura e co-construção da saúde mental. Dessa forma, o ECSM pode se constituir como uma oportunidade de construir uma visão mais ampla da saúde para todos os envolvidos - inclusive os profissionais de saúde mental- à medida que convida a todos a desconstruir os lugares estratificados que ocupam na cotidianidade.

Medard Boss (1976), psiquiatra que buscou desenvolver uma compreensão e uma prática para a área da Saúde Mental orientadas pela filosofia heideggeriana afirma que:

“(...) é possível nos abrirmos para outros modos de relação com o mundo e com o outro. Para isso, será necessário sair da visão do sujeito que exerce sua vontade possessiva de forma absoluta, a fim de possibilitar ser aquilo que se apresenta, ou seja, tornarmo-nos mais 
disponíveis ao compreendermos que "o domínio técnico sobre o mundo realiza apenas uma única possibilidade entre muitas outras da presença no mundo (...)". (p. 41)

O autor assim expressa a necessidade do profissional de saúde mental estar disponível para outras formas de relação, ao admitir que a técnica oferece uma forma de compreensão válida, porém não absoluta. Ao refletirmos acerca do ECSM, deparamo-nos com uma possibilidade que corresponde a uma necessidade da área de Saúde Mental de ampliar as formas de relação, uma vez que todos os envolvidos têm a oportunidade de se colocar de uma maneira mais aberta aos aspectos humanos do outro e de si mesmo. Assim, o ECSM cria espaço para novos encontros na área da saúde, construindo novas possibilidades de relação e compreensão.

Ao refletir sobre as possibilidades de cuidado da saúde mental, novamente é possível nos voltarmos para a filosofia proposta por Heidegger para compreender as particularidades do ECSM. Heidegger (1927/1986) descreveu, em Ser e Tempo, as estruturas ontológicas, ou seja, as estruturas de possibilidades essenciais do Dasein, que são a Compreensão, a Disposição Afetiva, a Queda, o Ser-para-a-morte e o Cuidado, entre outras. Dentre essas, o filósofo apontou para o Cuidado como um existencial fundante do existir humano, que constitui a essência do Dasein.

Heidegger dará o nome de Sorge, palavra alemã que pode ser traduzida para o português como cura ou cuidado, à estrutura ontológica que se constitui como ser do Dasein. No presente trabalho, será utilizada a tradução como Cuidado, que será identificada com letra maiúscula, quando designar a estrutura ontológica citada por Heidegger, para diferenciá-la do termo cuidado, no sentido comum, que designa ações de dimensão ôntica.

Para o filósofo, o Dasein está sempre cuidando de suas possibilidades existenciais, ou seja, da característica do Dasein de ter de ser e poder ser, não como uma ação intencional, controlável ou totalmente consciente, mas como resultado de uma autocompreensão e ação transformadoras (Heidegger, 1927/1986). Assim, o Cuidado compreende ações ônticas, como cuidar da saúde, da vida, e de outras pessoas, mas é mais do que o conjunto dessas ações ônticas, se constituindo como uma condição existencial do ser.

É importante ressaltar que faz parte do Cuidado a característica ontológica do Dasein de ser sempre em relação. A relação do Dasein com os entes intramundanos, cujo modo de ser é simplesmente dado, é denominada por Heidegger como Besorgen, que é traduzido por ocupação, enquanto a relação com o outro (ser-aî) é chamada Fursorge, e é traduzida como preocupação (Heidegger, 1927/1986). É relevante observar a diferenciação entre a relação que 
o Dasein estabelece com seus semelhantes e a relação que estabelece com os demais entes. Isso porque a relação estabelecida entre o Dasein e outros Dasein é estruturante em sua existência, e faz parte de sua característica existencial de ser-com.

Deste modo o filósofo caracteriza dois tipos fundamentais de preocupação: a preocupação substitutiva e a anteposição libertadora. A preocupação substitutiva é caracterizada por um modo de se relacionar com o outro marcado pela manipulação, direcionamento, substituindo o outro em sua própria tarefa de cuidar do sentido de sua existência, enquanto a anteposição liberadora é caracterizada por uma relação com o outro, percebendo-o em seu ser e permitindo que assuma suas responsabilidades e faça suas escolhas de maneira mais própria. (Heidegger, 1927/1986)

Heidegger (1927/1986) afirma ainda que há um tipo deficiente de preocupação presente na cotidianidade, que ele denomina como indiferença. Assim, da mesma maneira como o Dasein, sendo abertura, apreende-se de modo mais frequente e imediato de maneira velada, através de representações objetivantes, também em seu ser-com, ele se relaciona frequentemente como indiferente.

Pautado na noção de Cuidado de Heidegger, Ayres (2004) afirma que na área da saúde é importante que se perceba o encontro existente em toda relação terapêutica, para além da técnica voltada para um resultado, no qual estão presentes necessidades de compreensão e construção de si mesmo e do outro. Esse olhar para o encontro humano é estrutural no ECSM e remete ao Cuidado caracterizado por Heidegger, ao não se centrar em um fazer técnico buscando controle ou remissão de sintomas, mas em um espaço no qual as pessoas podem conversar sobre suas vidas e possibilidades, construindo sentidos a partir do encontro com os outros participantes.

O olhar para o fenômeno permite perceber uma diferença fundamental na atitude diante do outro que estrutura o ECSM, que o diferencia de outras iniciativas em saúde mental que, tomando a pessoa em sofrimento psíquico de forma reducionista, constrói intervenções com a finalidade de modificá-lo para eliminar seus “defeitos” (Feijoo, 2004). No ECSM o sofrimento pode adquirir um novo significado, além do de desajuste, e pode ser entendido como parte da existência, como um acontecimento ao qual todos estão sujeitos. Segundo Ayres (2001) as modalidades de tratamento focadas no controle das doenças se tornaram posturas limitadas ao olharem para os usuários de maneira objetificadora, supondo uma relação estática e individualizante na compreensão da saúde (ou da doença) dos mesmos.

Nesse sentido, podemos considerar que o ECSM, pela transformação do olhar para a saúde, ressalta a importância, já preconizada pela Reforma Psiquiátrica, da construção de 
ações de cuidado mais amplas, voltadas para a vida das pessoas, e não apenas para a supressão dos sintomas da doença. Este significado é compartilhado e reconhecido como uma possibilidade para todos os participantes, como descrito na unidade Reconhecimento de Semelhanças.

Dessa maneira, o ECSM está em contraposição à maneira como hegemonicamente se oferece atenção em Saúde Mental, em que os dispositivos de saúde estão frequentemente impregnados pelo paradigma biomédico, em que a forma de conhecimento predominante é a que considera o ser humano de forma reducionista e fragmentada. Assim muitas práticas em saúde têm uma visão restrita do usuário, valorizando o corpo e a doença em detrimento do olhar para as possibilidades de ser e seus sentidos, recebendo-o como um desajustado orgânica, psíquica e socialmente. (Costa-Rosa, 2000).

No ECSM, o cuidado é construído por todos os participantes que se encontram e se apropriam da proposta de estar com o outro compartilhando experiências. Dessa forma, consideramos que o ECSM constrói uma maneira de cuidado que ressalta a característica do Dasein como ser-com, uma vez que o evento se centra na possibilidade de compartilhamento entre os participantes e no reconhecimento da importância do outro na co-construção, tanto do evento, quanto da saúde mental de todos os envolvidos.

Nesse sentido, podemos pensar o ECSM como um dispositivo de cuidado que atua como um facilitador de novas possibilidades de ser e de relação. No evento, as pessoas são consideradas em sua totalidade, como pessoas com possibilidades, carências, dificuldades e recursos. E dessa forma, são convidadas para, juntas, partilhar suas experiências em um ambiente de escuta e respeito. Essa experiência possibilita a construção de novos sentidos para suas vidas e para o cuidado da saúde mental, que não se reduzem a busca de resultados, no sentido de corrigir inadequações e eliminar sintomas.

Ao refletirmos sobre as possibilidades de relações promovidas pelo ECSM, consideramos que o evento desconstrói a maneira de se relacionar com o outro presente nas modalidades de cuidado com a saúde que remetem ao conceito de Heidegger (1927/1986) de preocupação substitutiva. Tais práticas, presentes em instituições da Psiquiatria clássica, são criticadas pela Reforma Psiquiátrica, por se constituírem como uma tutela do usuário e configurarem uma modalidade de cuidado na qual o profissional de saúde é considerado como detentor da compreensão acerca dos usuários e de seus familiares, e por isso monopoliza as decisões a respeito do tratamento a ser dispensado aos mesmos.

O ECSM promove uma oportunidade de construção de cuidados mais afinados com a postura descrita pela fenomenologia de Heidegger (1927/1986) como anteposição 
libertadora, pois trata-se de uma maneira de se relacionar com o outro devolvendo a este a tutela por sua vida. Porém, novamente é importante ressaltar que, quando mencionamos que a estrutura do fenômeno oferece uma oportunidade de estabelecer uma nova maneira de se relacionar e de compreender o outro, não consideramos que essa possibilidade se realizará necessariamente. Os participantes do evento podem realizar tal possibilidade oferecida, e também podem não realizar essa possibilidade, pois a estrutura do fenômeno não determina a maneira como as pessoas reagirão à mesma. Nesse sentido, no ECSM, estará em jogo a possibilidade de ser, e caberá aos participantes a escolha de se abrir para essa proposta e construir juntos o encontro e novas possibilidades de existir, ou continuar repetindo os papéis estratificados.

Em um contexto em que se busca a superação do cenário de maus-tratos e desassistência no campo da saúde mental, o ECSM se constitui como um novo espaço de cuidado visando à transformação da atenção em Saúde Mental. A participação dos usuários e da comunidade é valorizada e a prática da interdição, relacionada à preocupação substitutiva é substituída pela prática da interlocução, relacionada à anteposição libertadora. Assim, no ECSM é criado um espaço para ouvir o participante em uma forma mais horizontal de relação entre os atores sociais envolvidos na produção de saúde, pois no evento os participantes estão reunidos em torno de suas semelhanças, ou seja, sua condição de ser humano, e dessa forma têm que lidar com sua saúde mental, seus sofrimentos e alegrias.

A horizontalização do poder entre profissionais de saúde e usuários do serviço é indicada, segundo Robaina (2010), como necessária no processo de transformação do cuidado proposto pela Reforma Psiquiátrica. Dessa maneira, podemos apontar o ECSM como lugar de promoção de novas possibilidades de ser-com, entre profissionais de saúde mental e usuários de serviço, mas também entre familiares, estudantes e demais participantes.

Os participantes são convidados para construir juntos, em uma relação de Valorização das pessoas e em um ambiente de Partilha de experiências, um lugar de cuidado com a saúde mental. Assim, a estrutura do ECSM colabora para responder à necessidade dos serviços de saúde citada por Wetzel e Kantorsi (2004), de transformação das relações estabelecidas entre usuários, família, profissionais e comunidade, e dos papéis sociais a eles associados.

O ECSM é aberto a toda a comunidade, não se restringindo a pessoas que estejam passando ou tenham passado por atendimento em serviço da rede assistencial de saúde mental. É importante promover uma modalidade de tratamento que conserve o contato do usuário com a família e a comunidade, uma vez que a família é considerada uma aliada no processo terapêutico, o que é reconhecido por vários estudos (Brusamarello et. al, 2011; 
Lefley, 1998) assim como a importância dos serviços de saúde também terem a família como foco de atenção (Bielemann et. al, 2009; Melman, 2006). Nesse sentido, o ECSM se caracteriza como um espaço que pode responder a essas necessidades à medida que é direcionado para usuários, familiares e para a comunidade em geral, buscando atuar na promoção de todos os envolvidos de maneira integrada.

Deste modo, o ECSM estabelece uma alternativa à visão presente na cotidianidade, marcada pelo preconceito e pela indiferença, ao promover uma interação capaz de aproximar pessoas normalmente afastadas nos serviços tradicionais de saúde, valorizando a todas e reconhecendo a semelhança entre elas, como seres humanos. Assim, durante a partilha das experiências, repetidas vezes se encontram relatos de pessoas que se identificam com as situações e emoções compartilhadas e expressam esse reconhecimento.

Ao promover um encontro que contempla os atores sociais da Saúde Mental, e principalmente por propor uma nova maneira de relação entre eles, fundado em uma atitude de cuidado que rompe com um modelo de relação dicotômico, marcado pela tutela, o ECSM se configura como uma proposta original que busca caminhos para a consolidação dos pressupostos do modelo psicossocial (Costa-Rosa, 2000). Todos os participantes são vistos como pessoas que podem ocupar um papel de protagonismo na construção de sua saúde mental e da saúde mental do outro, uma vez que são considerados capazes de oferecer acolhimento e cuidado.

Oliveira e Alessi (2003) afirmam que o objetivo do modelo de saúde vigente é substituir as práticas que produzem a exclusão e a marginalização dos usuários por ações que promovam a integração familiar e social dos mesmos. É possível observar que o ECSM aponta para essa direção ao ser essencialmente estruturado a partir da interação entre usuários, ex-usuários, familiares, profissionais e a comunidade, em um ambiente de escuta e respeito mútuo. Tal atitude perante o humano remete à proposta de criação de uma nova possibilidade de integração das pessoas junto ao corpo social, compreendida por Amarante (1996) como o conceito de reinserção social, que se constitui como um dos objetivos do cuidado em Saúde Mental a partir do movimento de Reforma Psiquiátrica.

No evento, a característica existencial de ser-com-os-outros é enfatizada, pois a estrutura do evento celebra a possibilidade de co-construção de si mesmo e da saúde mental a partir do encontro com o outro e da partilha de experiências com os demais. Nesse sentido, ao se constituir como uma Experiência Comovente, de Partilha e Valorização das Pessoas, que proporciona o Aprendizado e um espaço para a Gratidão, o ECSM contribui para o 
rompimento da indiferença que, segundo Heidegger, marca a maneira de ser-com da cotidianidade.

Nesse sentido, os participantes relataram satisfação com a oportunidade de contar suas experiências, de aprender e transformar a maneira como compreendem a si mesmos e ao outro durante o evento. A partir desses depoimentos é possível considerar que muitos participantes valorizaram essa possibilidade de ser-com e de construir a própria saúde mental no encontro com o outro.

Dessa maneira, o ECSM se configura como uma ação de cuidado em Saúde Mental, que se organiza de forma a propor novas possibilidades de existir, relacionar-se e de compreender, dentro do jogo de poder ser e ter de ser que marca a existência do homem, e assim proporciona uma oportunidade de experiência potencialmente transformadora a todos os atores sociais envolvidos na área da Saúde Mental.

Os participantes do ECSM relatam que a abertura para ouvir o outro provocou neles sentimentos, pensamentos e aprendizado, e a pluralidade de idéias e significados compartilhados cria a oportunidade, para o ouvinte, de se abrir a novas possibilidades de interpelação acerca do que ele vive. Tais características vão ao encontro de estudos recentes acerca da reabilitação psicossocial, que referem a necessidade de elaboração de estratégias que proporcionem ao usuário a oportunidade de retomar sua autonomia, aumentem a capacidade de trocas entre as pessoas e possibilitem a construção de novas relações sociais. (Pereira, 2007; Mielke et. al, 2011). A partir dos depoimentos, que podem ser observados nas unidades estruturais Aprendizado, Gratidão, Experiência Comovente, Satisfação e Reconhecimento de Semelhanças, é possível considerar que muitos participantes aderiram à proposta do Encontro, pois se abriram para essa nova possibilidade de serem construídos com o outro.

Segundo França Neto (2009), atualmente é importante perceber a interdição promovida não apenas pelo hospital psiquiátrico, mas também pela sociedade, que destitui o usuário de sua condição de cidadão. A partir dessa necessidade e da mudança de atitude diante do outro e da saúde mental que marca o evento, é possível considerar que o ECSM pode ter um potencial transformador para a comunidade, a partir da exploração de diferentes possibilidades de relação, sobretudo aquelas fundadas na anteposição libertadora, e que dão lugar ao devir. Nesse sentido, o ECSM se apresenta também como um serviço para a comunidade, pois promove desconstrução de preconceitos relacionados à saúde mental.

Como uma modalidade de encontro na área da saúde que procura criar novos espaços de relação e compreensão com o outro e uma nova atitude diante da saúde mental, rompendo 
com o olhar objetivante do antigo modelo, o ECSM se apresenta como uma alternativa inserida nas novas iniciativas propostas para a transformação do modelo assistencial. Nesse sentido, é possível dizer que o ECSM realiza uma articulação apontada como necessária entre os arranjos técnicos e um sentido mais rico e interativo na construção da saúde. (Merhy 2002)

É necessário ressaltar que o ECSM, abordado no presente estudo é uma prática que representa um momento de um processo maior e mais complexo de construção da saúde mental. Produto de uma série de encontros comunitários semanais e mensais, o ECSM é construído ao longo do ano todo, e também é articulado a serviços da rede assistencial em saúde mental. O presente estudo se concentrou em um momento, buscando sua descrição e os sentidos produzidos por essa prática, porém apresenta limites em termos da descrição do processo de produção do ECSM.

Assim, o presente estudo pode ser ampliado em pesquisas posteriores, que tenham como objetivo a compreensão da construção do encontro de maneira longitudinal. Outras possibilidades de ampliação da compreensão do ECSM seriam: a produção de novos estudos que abordem o significado que o ECSM possui para seus participantes; os sentidos que ele produziu nos serviços de saúde com os quais este é articulado; e as possibilidades que o ECSM desvelou na formação de estudantes e profissionais de saúde que participaram deste. 


\section{CONSIDERAÇÕES FINAIS}

No presente trabalho foi possível produzir um estudo sistematizado do Encontro Comunitário de Saúde Mental, que se configura como nova iniciativa de ação no campo da saúde mental. Construído em um cenário marcado pelos desafios da implementação das novas diretrizes da Saúde Mental, baseadas nos movimentos de Reforma Psiquiátrica, o ECSM tem se desenvolvido de maneira a se tornar uma ação direcionada à da construção de um cuidado com a saúde mental de acordo com os preceitos do modelo psicossocial, caracterizado por Costa-Rosa (2000). Assim o ECSM se configura como uma maneira de cuidado que ultrapassa as limitações do modelo biomédico, centrado na dicotomia doença-cura e na medicalização como principal terapêutica.

Através da proposta metodológica da Fenomenologia, foi possível desvelar o acontecer do ECSM, como havia sido delineado no objetivo do presente trabalho. Tal metodologia foi escolhida por sua característica de abertura para a compreensão do fenômeno estudado, suspendendo todas as ideias prévias que se tenha do mesmo. Uma vez que o ECSM é uma ação sobre a qual vários estudos estão se desenvolvendo, o olhar da Fenomenologia contribuiu para que as possibilidades vividas pelos participantes do evento pudessem ser desveladas.

A análise do material permitiu a construção das unidades de significado que compõem estrutura do fenômeno, a saber: Partilha, Valorização das Pessoas, Valorização das Relações, Reconhecimento de Semelhanças, Aprendizado, Experiência Comovente, Satisfação e Gratidão. As possibilidades desveladas no estudo apontaram para a elaboração de uma ação de cuidado através da construção de uma atitude diante do outro e da saúde mental. Essa atitude é marcada pela abertura para o outro, valorizado enquanto pessoa que, através da partilha de suas experiências pessoais e cotidianas, tem a possibilidade de contribuir não apenas para o próprio cuidado com a saúde mental, mas com a saúde mental de todos os envolvidos.

No ECSM, as relações entre as pessoas são valorizadas, e ao longo do evento é possível perceber que este se estrutura a partir de uma proposta de horizontalização dessas relações. As preconcepções e estigmas que muitas vezes acompanham os participantes sejam eles usuários de serviço de saúde mental, familiares, profissionais da área, estudantes, ou pessoas da comunidade - não são o foco da interação, e dessa maneira podem ser desconstruídos, diante do Reconhecimento de Semelhanças proporcionado pela interação promovida no evento, seja na composição das mesas redondas ou no momento de fala aberta. 
Tais características remeteram ao pensamento do filósofo Martin Heidegger a respeito do Ser e do Cuidado, característicos da existência humana. Uma articulação entre o pensamento do filósofo e o Encontro foi construída para aprofundar a compreensão do evento e para ampliar a reflexão acerca das possibilidades do mesmo, inserido no atual cenário da saúde mental.

Segundo Heidegger (1927/1986), o homem é diferente de todos os demais entes pois seu modo de ser não é simplesmente dado, mas é um movimento, onde suas possibilidades de ser estão sempre em jogo. Uma articulação com esse conceito foi possível devido ao ECSM ser constituído como um lugar onde as pessoas têm a oportunidade de olhar para si mesmas e para o outro numa perspectiva de ser como movimento, sem a identificação com um ser objetivado, seja ele em um estado de saúde ou de doença. Em muitas das características estruturais do ECSM é possível estabelecer o diálogo com o conceito proposto pelo filósofo, como a Partilha, a Valorização das Pessoas, o Reconhecimento de Semelhanças e o Aprendizado, pois em todos eles a característica de vir-a-ser dos participantes é enfatizada.

Outro conceito proposto por Heidegger (1927/1986), que pôde ser usado para ampliar a reflexão acerca do ECSM é o Cuidado. Segundo o filósofo, o Cuidado é uma característica essencial do Dasein e está ligado à característica do mesmo ser sempre em relação, ou seja, ser-com. O diálogo entre essa estrutura existencial e o ECSM aconteceu devido a características como a Valorização das Relações, a Experiência Comovente e a Gratidão, nas quais o papel do outro na construção de si-mesmo e da saúde mental é enfatizado, rompendo com a indiferença que marca a cotidianidade.

É possível considerar que o presente trabalho atingiu os objetivos propostos de construir um estudo sistematizado e fazer uma descrição compreensiva do fenômeno. A partir das características desveladas é possível apontar ECSM como uma iniciativa original e relevante no campo da saúde mental, que trabalha no sentido das proposições da Reforma Psiquiátrica, e que contribui para a construção da saúde mental de todos os envolvidos. Novos estudos se fazem necessários para ampliar a sistematização do conhecimento desta nova iniciativa. 


\section{REFERÊNCIAS BIBLIOGRÁFICAS}

Almeida, K. S., Dimenstein, M., Severo, A. K. (2010). Empoderamento e atenção psicossocial: notas sobre uma associação de saúde mental. Interface - Comunicação, Saúde, Educação. 14, (34), pp 577-589

Amarante, P. (1996). O homem e a serpente - outras histórias para a loucura e a psiquiatria. Rio de Janeiro: Fiocruz.

Amarante, P. (2001). Sobre duas proposições relacionadas à clínica e à reforma psiquiátrica. In: Quinet, A. (Org.). Psicanálise e psiquiatria: controvérsias e convergências. Rio de Janeiro: Rios Ambiciosos.

Amarante, P. D. C. \& Torre, E. H. G. (2001). Constituição de novas práticas no campo da Atenção Psicossocial: análise de dois projetos pioneiros na Reforma Psiquiátrica no Brasil. Saúde em Debate, 25 (58), pp 26-34.

Ayres, J. R. C. M. (2001). Sujeito, intersubjetividade e práticas de saúde. Ciência \& Saúde Coletiva, 6 (1) pp63-72.

Ayres, J. R. C. M. (2004). O cuidado, os modos de ser (do) humano e as práticas de saúde. Saúde e Sociedade, 13 (3) pp16-29.

Basaglia, F. (1985). A instituição negada: relato de um hospital psiquiátrico. Rio de Janeiro: Graal.

Bielemann, V.L.M.; Kantorski, L.P.; Borges, L.R.; Chiavagatti, F.G.; Willrich, J.Q. \& Souza, A.S. (2009). A inserção da família nos centros de atenção psicossocial sob a ótica de seus atores sociais. Texto \& Contexto - Enfermagem, 18 (1) pp 131-9.

Boemer, M. R.(1994). A condução de estudos segundo a metodologia de investigação fenomenológica. Revista Latino Americana de Enfermagem, 2 (1) pp 83-94.

Boss, M.(1976). Análise Existencial - Daseinsanalyse. (Como a Daseinsanalyse entrou na Psiquiatria). Revista da Associação Brasileira de Daseinsanalyse, (2), pp 5-23.

Boss, M.(1977). O-modo-de-ser-esquizofrênico à luz de uma fenomenologia Daseinanalítica. Revista da Associação Brasileira de Daseinsanalyse, (3), pp 5-28. 
Brasil. Congresso Nacional. (1989). Projeto de lei $n^{0}$ 3.675/89, de 27 de setembro de 1989. Dispõe sobre a extinção progressiva dos manicômios e dá outras providências. Diário Oficial da União [da República Federativa do Brasil], Brasília (DF), 27 set.

Brasil. Ministério da Saúde. (2002). Relatório final da III Conferência Nacional de Saúde Mental. Brasília:Conselho Nacional de Saúde.

Brasil, Ministério da Saúde. Brasil comemora dez anos da reforma psiquiátrica com avanços na assistência à saúde mental pelo SUS. <http://portal.saude.gov.br/portal/aplicacoes/noticias/ default.cfm?pg=dspDetalheNoticia\&id_area=124\&CO_NOTICIA=12443> Acesso em: 10. Ago. 2011

Brusamarello, T.; Guimarães, A. N.; Labrocini, L. M; Mazza, V. A. Maftum, M. A. (2011) Redes sociais de apoio de pessoas com transtornos mentais e familiares. Texto \& ContextoEnfermagem, 1 (20), pp 33-40

Campos, P. H. F. \& Soares, C. B.(2005). Representação da sobrecarga familiar e adesão aos serviços alternativos em saúde mental. Psicologia em Revista, 11 (18), pp 219-237.

Ceccim, R. B. \& Feuerwerker, L. C. M. (2004). O quadrilátero da formação para a área da saúde: ensino, gestão, atenção e controle social. Physis: Revista Saúde Coletiva, 14 (1), pp 4165.

Coltro, A.(2000). A Fenomenologia: Um enfoque metodológico para além da modernidade. Caderno de Pesquisas em Administração, 1(11), pp 37-45.

Cohn, A.,(2000). Cidadania e Formas de Responsabilização do Poder Público e do Setor Privado pelo Acesso, Eqüidade, Qualidade e Humanização na Atenção à Saúde. $<$ http://www. saude.gov.br/11cns/index_11cns.htm>.

Côrtes, S. M. V., (2002). Balanço de Experiências de Controle Social, para além dos Conselhos e Conferências no Sistema Único de Saúde Brasileiro: Construindo a Possibilidade de Participação dos Usuários. <http://www.saude.gov.br/11cns/cns_ balanco.htm>.

Cotta , R. M. M. et al. (2000). Participación social y sistemas sanitários en Brasil vs España. Centro de Salud, 8: pp 450-455.

Costa-Rosa, A. (2000) O modo psicossocial: um paradigma das práticas substitutivas ao modo asilar. In: Amarante, Paulo (org.). Ensaios: subjetividade, saúde mental, sociedade. (pp. 141168). Rio de Janeiro: Fiocruz. 
Dartigues, A. (2003). O que é a fenomenologia? São Paulo: Centauro.

Delgado, P.G.G.(1987). Perspectivas da psiquiatria pós-asilar no Brasil. Cidadania e loucura: políticas de saúde mental no Brasil. Petrópolis- Rio de Janeiro: Vozes-Abrasco.

Delgado, P. G. G.(1991) Determinantes institucionais da cronificação. Jornal Brasileiro de Psiquiatria, 40 (3), pp 117-125.

Feijoo, A. M. L. C.(2004). A psicologia clínica: técnica e téchne. Psicologia em estudo, 9 (1), pp 87-93.

Figueiró, R. A. (2009). A ajuda mútua entre os usuários de CAPS: o papel do serviço no empoderamento dos usuários. Dissertação (Mestrado) - Programa de PósGraduação em Psicologia, Universidade Federal do Rio Grande do Norte, Natal.

Fogel, G. (1996). Martin Heidegger, et coetera e a questão de técnica. Cadernos do Departamento de Filosofia PUC - Rio, 10 (2), pp 11- 67

Forghieri, Y. (1993). Psicologia fenomenológica. São Paulo: Pioneira

França, L. (1978) Noções de história da filosofia. (22ªed.). Rio de Janeiro: Agired.

França Neto, O. (2009). Uma ética para os novos desdobramentos da reforma psiquiátrica. Ágora: estudos em teoria psicanalítica, 12 (1), pp 119-129.

Giorgi, A. \& Sousa, D. (2010). Método Fenomenológico de Investigação em Psicologia. Lisboa: Fim de século.

Gonçalves, S. et al. (2002) Lar de Acolhimento: implantação de um módulo residencial. Jornal Brasileiro de Psiquiatria, 51 (6), pp 391-396.

González Rey, F. (2005). Pesquisa qualitativa e subjetividade. São Paulo: Thomson.

Heidegger, M. (1927/1986). Ser e tempo. Petrópolis: Vozes.

Holanda, A. (2002). O resgate da fenomenologia de Husserl e a pesquisa em psicologia. Tese de doutorado, Pontifícia Universidade Católica de Campinas, Campinas.

Husserl, E. (1965). A filosofia como ciência de rigor. Coimbra: Atlântida 
Husserl, E. (1985). Idées directrices pour une phénoménologie et une philosophie phénoménologique pures. Paris: Gallimard.

Husserl, E. (1992). Conferências de Paris. Lisboa: Edições 70.

Kantorski L.P.(2001). A reforma psiquiátrica: um estudo parcial acerca da produção científica da temática. Revista Elétronica de Enfermagem 3 (1) Disponível em http://www. fen.ufg.br/revista.

Kinoshita, R.T. (1987). Uma experiência pioneira: a reforma psiquiátrica italiana.In: Marsiglia, R.G.; Dallari, D. A.; Costa, J.F.; Moura Neto, F.D.M.; Kinoshita, R.T. \& Lancetti, A. Saúde mental e cidadania. (pp.67-83). São Paulo: Edições Mandacaru.

Kraepelin, E. (1988). Introdución a la clínica psiquiátrica. Madri:, Ediciones Nieva.

Lima, L.A. \& Teixeira, J.M. (1995). Assistência à saúde mental no Brasil: do mito de excesso de leitos psiquiátricos à realidade da falta de serviços alternativos de atendimento. Jornal Brasileiro de Psiquiatria, 44 (2), pp71-76.

Lefley, H. P. (1998). Families, culture, and mental illness: constructing new realities. Psychiatry: Interpersonal and Biological Process, 61 (4), pp335-355.

Lussi, I. A. O. ; Pereira, M. A. O.; Pereira Júnior, A. (2006). A proposta de reabilitação psicossocial In: Saraceno, B. Um modelo de auto-organização? Revista Latino-Americana de Enfermagem, Ribeirão Preto, 13 (3), pp 448-456.

Martins, J. \& Bicudo, M. A. V. A (1989) pesquisa qualitativa em psicologia: Fundamentos e Recursos Básicos. Editora Moraes, São Paulo.

Masini, E. F. S.(1989). O enfoque fenomenológico de pesquisa em educação. In: Fazenda, I. (org.) Metodologia da pesquisa educacional. São Paulo: Cortez.

Mello, R. \& Furegato, A. R. F. (2008). Representações de usuários, familiares e profissionais acerca de um centro de atenção psicossocial. Revista de Enfermagem da Escola Anna Nery, 12 (3), pp. 457-464.

Melman J. (2006). Família e doença mental: repensando a relação entre profissionais de saúde e familiares. ( $2^{\mathrm{a}}$ ed.). São Paulo: Escrituras.

Mendes, E. V. (2006). Uma agenda para a saúde. 2.ed. São Paulo, Hucitec 
Merhy, E. E. (2002). Saúde: a cartografia do trabalho vivo em ato. São Paulo: Hucitec.

Michelazzo, J. C. (1999) Do um como princípio ao dois como unidade - Heidegger e a construção do real. São Paulo: Anna Blume.

Mielke, F. B.; Kantorski, L. P.; Olschowsky, A. \&, Jardim, V. M. R. (2011) Características do cuidado em saúde mental em um CAPS na perspectiva dos profissionais. Trabalho, educação e saúde, 9 (2), pp 265-276.

Moura Castro, C. (1997). A prática da pesquisa. São Paulo: McGraw Hill do Brasil.

Nunes, M.; Jucá, V. J. \& Valentim, C. P. B.(2007). Ações de saúde mental no Programa Saúde da Família: confluências e dissonâncias das práticas com os princípios das reformas psiquiátrica e sanitária. Cadernos de Saúde Pública, 23 (10), pp 2375-2384.

Oliveira, A.G.B. \& Alessi, N.P. (2003). O trabalho de enfermagem em saúde mental: contradições e potencialidades atuais. Revista Latino-Americana de Enfermagem, 11(3), pp.333-340.

Pereira, M. A. O. (2007). A reabilitação psicossocial no atendimento em saúde mental: estratégias em construção. Revista Latino-Americana de Enfermagem, 15 (4) pp 658-664.

Randemark, N. F. R.; Jorge, M. S. B. ; Queiroz, M. V. O. (2004). A reforma psiquiátrica no olhar das famílias. Texto e contexto em enfermagem, 13 (4), pp 543-550.

Robaina, C. M. V. (2010). O trabalho do Serviço Social nos serviços substitutivos de saúde mental. Serviço Social \& Sociedade, (102), pp 339-351.

Rosa, L. C. S. (2002). Os saberes construídos sobre a família na área da saúde mental. Serviço Social \& Sociedade, 71, pp 339-351.

Rotelli F., Leonardis O. \& Mauri D. (1990). Desinstitucionalização uma outra via. In Nicácio, F. (Org.). Desinstitucionalização. (pp. 17-60). São Paulo: Hucitec.

Sá, R. N. et al. (2006) Solidão e relações afetivas na era da técnica. Revista do Departamento de Psicologia UFF. 18 (2), pp 111-124

Sanders, P. (1982). Phenomenology: A new way of viewing organizational research. Academy of Management Review, 7 (3), pp 353-360. 
Saraceno, B. (2001). Libertando identidades: da reabilitação psicossocial à cidadania possível. ( $2^{\text {a }}$ ed.). Rio de Janeiro: TeCorá.

Suiyama’ R. C. B.; Rolim, M. A.; Colvero, L. A.(2007). Serviços residenciais terapêuticos em saúde mental: uma proposta que busca resgatar a subjetividade dos sujeitos? Saúde e Sociedade, 16 (3), pp 102-110.

Vattimo, G. (1986). Las aventuras de la diferencia, pensar después de Nietzsche y Heidegger. Tradução de Juan Carlos Gentile. Barcelona: Ediciones Península.

Vázquez et al. (2003) Participação social nos serviços de saúde: concepções dos usuários e líderes comunitarios em dois municipios do Nordeste do Brasil. Cadernos de Saúde Pública, 19, (2), pp579-591.

Wetzel C. \& Kantorski L. P. (2004). Avaliação de serviços em saúde mental no contexto da reforma psiquiátrica. Texto contexto - enfermagem, 13 (4), pp 543-548.

Zambenedetti,G. (2009). Dispositivos de integração da rede assistencial em saúde mental: a experiência do Serviço de Saúde Dr. Cândido Ferreira. Saúde \& Sociedade, 18 (2), pp 334345.

Yasui, S. \& Costa-Rosa, A.(2008). A Estratégia de Atenção Psicossocial: desafio na prática dos novos dispositivos de Saúde Mental. Saúde em Debate, 32, (78/79/80) pp27-37 


\section{ANEXOS}

\subsection{Autorização do Comitê de Ética em Pesquisa - Anexo 1}

UNIVERSIDADE DE SÃO PAULO
FACULDADE DE FILOSOFIA, CIENCIASELERAS DE R

DADE DE FILOSOFIA, CIÊNCIAS E LETRAS DE RIBEIRÃO PRETO

DE ETICA EMPESQUISA-CEP

Of.CEtP/FFCLRP-USP.003/2010-8/3/2010

Senhor(a) Pesquisador(a):

Comunicamos a V. Sa. que o trabalho intitulado "ESTUDO dos ENCONTROS E GRUPOS COMUNITARIOS DE SAÚDE MENTAL: DESCRIÇĀO E AVALIAÇÃO DE RESULTADOS", foi analisado pelo Comitê de Ética em Pesquisa da FFCLRP. USP, e, enquadrado na categoria: APROVADO, de acordo com o Processo CEP. FFCLRP n 480/2009 - 2009.1.2282.59.3.

Atenciosamente,

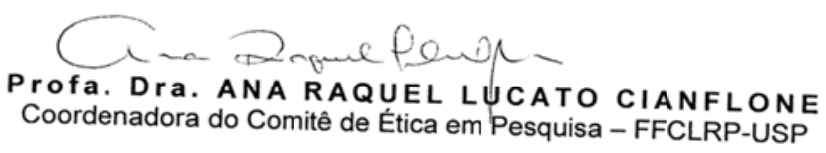

Ilustrissimo(a) Senhor(a):

Profa. Dra. Carmen Lúcia Cardoso

Docente do Departamento de Psicologia e Educação

Desta FFCLRP-USP

CEP-FFCLRP-USP - coetp@ffclrp.usp.br Fone: (016) 3602-3653 - Fax: (016) 3633-5015 Avenida Bandeirantes, 3900 - Bloco A - 14040-901 - Ribeirão Preto - SP - Brasil 